\title{
Allocation, stress tolerance and carbon transport in plants: How does phloem physiology affect plant ecology?
}

Running title: Phloem ecophysiology

Jessica A. Savage ${ }^{1}$, Michael J. Clearwater ${ }^{2}$, Dustin F. Haines ${ }^{3}$, Tamir Klein ${ }^{4}$, Maurizio Mencuccini ${ }^{5,6}$, Sanna Sevanto ${ }^{7}$, Robert Turgeon ${ }^{8}$ and Cankui Zhang ${ }^{9}$

${ }^{+}$Arnold Arboretum of Harvard University, 1300 Centre Street, Boston, MA 02131, USA

${ }^{2}$ School of Science, University of Waikato, Hamilton 3240, New Zealand

${ }^{3}$ Department of Environmental Conservation, University of Massachusetts, 160 Holdworth Way, Amherst, MA 01003, USA

${ }^{4}$ Institute of Botany, University of Basel, Schoenbeinstrasse 6, 4056 Basel, Switzerland

${ }^{5}$ School of GeoSciences, University of Edinburgh, Crew Building, West Mains Road, EH9 3JN Edinburgh, UK

${ }^{6}$ ICREA at CREAF, Campus de UAB, Cerdanyola del Valles, Barcelona, 08023, Spain

${ }^{7}$ Earth and Environmental Sciences Division, Los Alamos National Laboratory, Los Alamos, NM 87545, USA

${ }^{8}$ Plant Biology Section, School of Integrative Plant Science, Cornell University, Ithaca, NY 14853, USA

${ }^{9}$ Department of Agronomy, Purdue University, West Lafayette, IN 47907, USA

Corresponding author:

Jessica A. Saväge

jsavage@fas.harvard.edu

1300 Centre Street

Boston, MA 02131

This article has been accepted for publication and undergone full peer review but has not been through the copyediting, typesetting, pagination and proofreading process which may lead to differences between this version and the Version of Record. Please cite this article as doi: $10.1111 /$ pce. 12602 


\section{SUMMARY STATEMENT}

This review highlights the important but understudied role of phloem physiology in mediating how plants interact with their biotic and abiotic environment and shaping larger ecological patterns. We focus on three critical areas of current research: interactions between the xylem and phloem, carbon fluxes both in plants and at the ecosystem-scale, and interactions between plants and their biotic environment. The goal of this review is to draw attention to the critical role of carbon transport in plant physiological ecology and outline many of the questions that remain to be answered about this critical part of the plant vascular
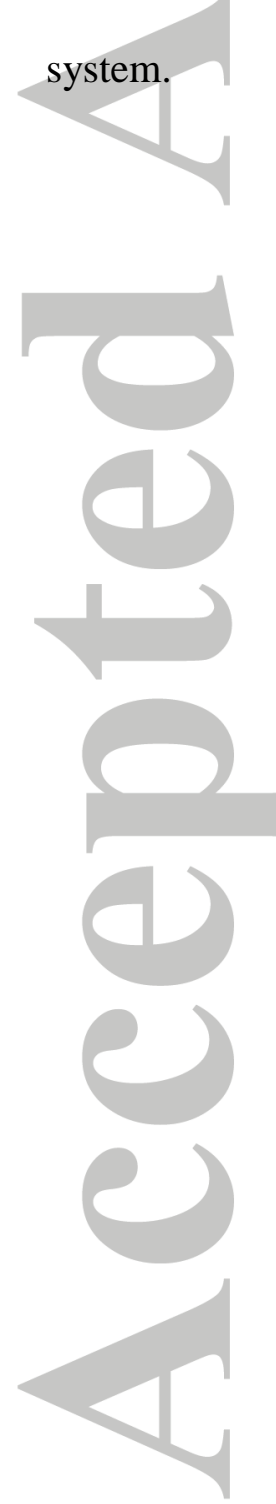


\section{ABSTRACT}

Despite the crucial role of carbon transport in whole plant physiology and its impact on plantenvironment interactions and ecosystem function, relatively little research has tried to examine how phloem physiology impacts plant ecology. In this review, we highlight several areas of active research where inquiry into phloem physiology has increased our understanding of whole plant function and ecological processes. We consider how xylemphloem interactions impact plant drought tolerance and reproduction, how phloem transport influences carbon allocation in trees and carbon cycling in ecosystems, and how phloem function mediates plant relations with insects, pests, microbes and symbiotes. We argue that in spite of challenges that exist in studying phloem physiology, it is critical that we consider the role of this dynamic vascular system when examining the relationship between plants and their biotic and abiotic environment.

Keyword Index: phloem transport, growth, defense, drought, xylem transport, reproduction, rhizosphere, carbon cycle 


\section{INTRODUCTION}

Carbon fixed by plants serves as the basis of all life in terrestrial habitats, but there are still many questions that remain about how plants invest carbon during their lifetimes (Körner, 2003, Sala et al., 2012) and how carbon allocation affects many ecological processes ranging from community assembly to carbon cycling (Grime, 2006, Migliavacca et $a l ., 2011)$. The majority of carbon used by vascular plants is not used where it is fixed but is transported to other metabolically active areas. This transport occurs in the phloem, a part of the vascular system that moves carbohydrates from photosynthetic and storage tissue (sources) to areas of active growth and metabolism (sinks). Because carbon transport is influenced by source and sink activity, it can integrate changes that occur throughout the plant, potentially influencing everything from growth and allocation to defense and reproduction (Fig. 1). The phloem's role in shaping many ecological processes has intrigued scientists for decades, but proving a direct connection between phloem physiology and plant ecology remains challenging.

Carbon transport occurs in a series of stacked cells, sieve elements, that in angiosperms form long continuous conduits called sieve tubes (for details on cell ultrastructure, see Froelich et al., 2011). Unlike transport cells in the xylem, sieve elements are under positive pressure and have intact cellular membranes (for recent reviews on phloem physiology, see De Schepper et al., 2013 and van Bel, 2003). In the phloem, there are other cell types including parenchyma and fibers, and of particular importance are the companion cells in angiosperms which are often responsible for loading sugar into the phloem and for helping maintain metabolic function of neighboring sieve tube elements (van Bel \& Knoblauch, 2000). Carbohydrates enter the phloem using one or a combination of passive and active loading mechanisms (see later section on PHLOEM LOADING), which require 
different sugar concentration gradients in the mesophyll and vary in the amount of symplastic continuity that exists between the vascular and ground tissue.

It is currently believed that phloem transport is driven by a pressure differential between the source and sink generated by local osmotic gradients in each tissue. This idea was first proposed by Ernst Münch (1930) and is the most widely accepted mechanism for phloem transport (for further discussion, see Knoblauch \& Peters, 2010). This mechanism allows for transport to occur in multiple directions but also means that changes in the source and sink tissue, including those triggered by the biotic and abiotic environment (reviewed by Lemoine et al., 2013) such as drought (Sevanto, 2014), may alter phloem transport. The downstream effects of these changes can influence the movement of carbohydrates (Savage $e t$ al., 2013) and phloem-mobile informational signals and secondary compounds (for reviews on molecular trafficking, see Turgeon \& Wolf 2009 and Lucas et al. 2013). These effects place the phloem in a central position for mediating plant-environment interactions and suggest that phloem structure could have important implications for a variety of processes from growth to reproduction (Fig. 1, Petit \& Crivellaro, 2014, Savage et al., 2015, Woodruff, 2014).

In this review, we describe research that provides a foundation for future work considering phloem physiology in an ecological and evolutionary context. We focus on three broader topics: carbon-water interactions, carbon fluxes in plants and ecosystems, and biotic interactions. For each of these topics, we provide discrete examples of how a phloem-focused line of inquiry could or already has enriched the field of physiological ecology. The aim of this review is to demonstrate the breadth of research influenced by phloem physiology and how research on this critical part of the vascular system can enhance our understanding of plant ecology and ecosystem function. 


\section{CARBON-WATER INTERACTIONS}

Many types of environmental stress including drought and freezing temperatures can jeopardize the integrity of the water transport system. Because the ability of plants to survive these conditions is influenced by aspects of xylem structure and function (Davis et al., 1999, Ewers, 1985, Hacke \& Sperry, 2001, Hacke et al., 2001), research on this part of the vascular system has become central to the discipline of physiological ecology (e.g., Ackerly, 2004, Jacobsen et al., 2007, Zanne et al., 2014). However, in all plants the xylem and the phloem occur in close proximity, and there is increasing evidence that a tight hydraulic connection (Bull et al., 1972, Minchin \& Lacointe, 2005, Ohya et al., 2008, Sevanto et al., 2011, van Bel, 1978) supports their transport processes (Knoblauch \& Peters, 2010, van Bel, 1990, Zwieniecki et al., 2004). Considering this fact, xylem-phloem interactions could significantly impact the nature of hydraulic stress and have large implications for plant function, growth and reproduction.

\section{What happens to phloem transport when xylem water potential changes?}

Experiments and modeling studies have revealed that most of the time the xylem acts as a water source for the phloem (Hölttä et al., 2006, Windt et al., 2006), but in certain situations, e.g. close to strong sinks (Sevanto et al., 2003), or during drought (Sevanto et al., 2005, Zweifel et al., 2000), phloem tissue including sieve tubes, parenchyma, and fibers may act as an additional water resource for the xylem (Fig. 2). Even if the volume of the phloem is a fraction of the volume of the xylem, it can contribute significantly to the transpiration stream because of its higher elasticity. From simultaneous measurements of phloem and xylem diameter variations, it can be estimated that in a tree with a stem diameter of $\sim 15 \mathrm{~cm}$, phloem contributes roughly $0.35 \mathrm{dl}$ of water per every meter of tree height (values taken from 
Acer rubrum, L., in Sevanto et al., 2011), which, in a $10 \mathrm{~m}$ tree can contribute to about $6 \%$ of its total daily water loss (Sevanto et al., 2008).

From the point of view of phloem transport, a tight hydraulic connection with the xylem is beneficial in allowing for easy access to water, but it has a trade-off: xylem water potential may influence phloem transport (Hölttä et al., 2009, Hölttä et al., 2006, Sala et al., 2010). Water exchange between the xylem and the phloem can be described as flow in a porous medium, where the flow rate depends on the water potential gradient and the hydraulic conductivity between the tissues (Hölttä et al., 2006, Sevanto et al., 2011). As a result, hydraulic conductivity determines the magnitude of flow rates obtained with a certain pressure gradient and how fast xylem water potential changes propagate to the phloem tissue. Because measuring hydraulic conductivity between the xylem and the phloem is very challenging, only an order of magnitude estimate exists (Salleo et al., 2004, Sevanto et al., 2011, Wan et al., 2004). To our knowledge, the estimated conductivity is high enough that at any timescale relevant to the whole plant, the phloem conduits are in hydraulic equilibrium with the surrounding apoplast (Thompson \& Holbrook, 2003) as well as with the xylem (Daudet et al., 2005, Hölttä et al., 2006, see also Hölttä et al., 2009), which has clear benefits to plants. Hydraulic equilibrium between the xylem and the phloem, for example, prevents rapid variations in plant water potential from causing changes in phloem turgor and unduly disturbing transport under most conditions (Thompson \& Holbrook, 2003).

The influence of xylem water potential on phloem transport has recently emerged in connection with drought mortality studies of trees (Fig. 2, see McDowell \& Sevanto, 2010, Sala et al., 2010, Sevanto, 2014). As described above, the lower the xylem tension (less negative the water potential), the easier it is for the phloem to obtain the water needed for transport. Therefore, theoretically, phloem transport should be easiest at night or during wet seasons (Hölttä et al., 2009, Hölttä et al., 2006). The high solute concentrations needed for 
osmotic adjustment during high xylem water tension, if built up with soluble sugars, may increase the viscosity of phloem sap and potentially block phloem transport (Hölttä et al., 2009, Hölttä et al., 2006). Such a blockage could have consequences for plant survival (McDowell \& Sevanto, 2010, Sala et al., 2010). However, if the conduits are hydraulically connected to the surrounding tissues and water in the apoplast, any change in osmotic concentration inside a conduit is immediately compensated for by inflow of water balancing the viscosity increase. The little empirical evidence we have on phloem responses to drought suggests that phloem turgor will collapse well before things get too "sticky" in relatively isohydric plants (Sevanto, 2014). This collapse may lead to a temporary increase in water available for the xylem, but ultimately promotes hydraulic failure. This way even wellwatered plants that cannot maintain phloem turgor because of depleted carbohydrate reserves can show symptoms of hydraulic failure (O'Brien et al., 2014, Sevanto, 2014).

The hydraulic connection between the xylem and phloem also necessitates that the structure of both tissues be balanced so that water supply and carbon transport needs match. This has implications for the relative thicknesses of xylem and phloem tissues and relative diameters of conduits (Hölttä et al., 2009, Jyske \& Hölttä, 2015) in relation to photosynthetic capacity and stomatal control (Nikinmaa et al., 2013). Phloem transport capacity depends on xylem water potential, which is linked with xylem water transport capacity (conduit number and size). Therefore, large structural investments in the xylem that improve its transport capacity reduce the need to invest in phloem structure (Hölttä et al., 2009). This implies that plants with wide xylem conduits or plants that keep their xylem water potential relatively constant (isohydric plants) may function with less phloem than plants that have low xylem conductivity or regularly experience low xylem water potentials (anisohydric plants) (Sevanto unpublished data). 
Despite increasingly sophisticated models, greater computing power and an improved biophysical understanding of the processes governing coupled xylem-phloem transport in plants, empirical evidence of how plant stature and growth conditions are related to phloem transport remains limited (see next section on CARBON FLUXES IN PLANTS AND ECOSYSTEMS). More anatomical and physiological data are needed to better understand the complex interactions that occur between the xylem and phloem from the source to the sink and to truly reveal the consequences of this interaction for plant ecology and evolution.

\section{How are flowers and fruit hydrated?}

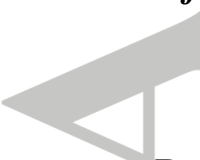

Because reproductive organs often serve as strong carbon sinks, xylem and phloem interactions can significantly impact water and solute movement into and out of developing flowers and fruit. Ernst Münch (1930) hypothesized that the phloem in the pedicel supplies both the water and solute requirements of growing buds and fruit, with transpiration considered negligible and excess water returned to the plant via the xylem (Fig. 3). However, calculations of phloem water flows based on dry weight growth and respiration rates suggest the potential rate of supply is limited, unless either the phloem sap is very dilute, risking loss of turgor (Chapotin et al., 2003), or there are large alternative sinks for carbon, such as accelerated respiration, catabolism of carbohydrates (Tarpley \& Sassenrath, 2006), or copious nectar production (Chapotin et al., 2003, De la Barrera \& Nobel, 2004). For these reasons phloem-only hydration of flowers must be energetically demanding compared to xylem supply, suggesting that the adaptive benefit of having flowers that are "hydraulically isolated" from daily and seasonal fluctuations in the xylem may be high (Feild et al., 2009, Galen, 2005). 
Whilst direct measurement of phloem flow is difficult, the relative contributions of the phloem and xylem to floral development have been inferred from water potential gradients. In the small number of species examined the water potential of the perianth is often higher than the subtending stem, indicating that water cannot be flowing towards the flower in the xylem (Chapotin et al., 2003, Lin, 1997, Trolinder et al., 1993). More recently it was proposed that dual phloem / xylem hydration is an ancestral trait, whilst exclusive phloem supply is a more advanced characteristic of the eudicotyledons, selected for as the angiosperms diversified and colonized less mesic habitats (Feild et al., 2009). In reality the concept of a dichotomy between phloem-only and xylem plus phloem hydration is probably overly simplistic (Roddy et al., 2013). The number of taxa for which flower water relations have been examined is very low, and there have been no direct observations that separate phloem and xylem flows in pedicels or within floral organs (Windt et al., 2009). We expect that continued investigation will reveal a range of variation in the mechanism of floral hydration.

Compared to flowers, the role of the phloem in fruit development is better understood. Generally, both the phloem and xylem contribute to early development, but phloem supply becomes more important during ripening (Matthews \& Shackel, 2005) because of reduced hydraulic conductance in the xylem (Choat et al., 2009, Mazzeo et al., 2013) and lower apoplastic water potential gradients (Bondada et al., 2005). This transition is typically accompanied by reduced growth and declining fruit surface conductance and transpiration rates (Clearwater et al., 2012, Greer \& Rogiers, 2009), lowering the demand for xylem water. Across species there may be a correlation between fruit surface conductance, the balance between phloem and xylem supply, and tolerance of water stress. For example, phloem only supply occurs throughout development of fruits of the desert plant Opuntia Mill. (Nobel et al., 1994, Nobel \& De la Barrera, 2000) and Gossypium L.(Trolinder et al., 1993, van Iersel 
et al., 1994, Wullschleger \& Oosterhuis, 1990), the warm climate crop cotton. However, there have been no broad comparisons of fruit transpiration rates and vascular functioning.

Another possibility is that the xylem acts to buffer any imbalances between transpiration, growth and more constant inward flows of phloem water (Fig. 3; Choat et al., 2009). Continuously circulating or temporally oscillating flows have been measured for several species including kiwifruit, Actinidia chinensis Planch. (Clearwater et al., 2012, Clearwater et al., 2009, Higuchi \& Sakuratani, 2005, Windt et al., 2009, Yamamoto, 1983). In this species, models show the amount of inward flow in the xylem decreases with decreasing assumed phloem sap concentration, but within the likely range of phloem concentrations there is always a requirement for some inward xylem flow. For xylem flow to always be zero or outward, as a 'phloem-only' paradigm suggests, the modelled phloem concentration must be set below known physiological concentrations, and loss of phloem turgor is predicted. The same problem has been raised for phloem-only floral hydration (Chapotin et al., 2003). However, it is possible that variation in the overall contribution of the phloem to fruit development is correlated with interspecific differences in phloem sap concentration. For example, in fruits of Opuntia, phloem-only supply is supported by dilute phloem sap (Nobel et al., 1994, Nobel \& De la Barrera, 2000).

Another factor that contributes to changes in fruit hydration during development is phloem unloading between sieve elements and sink tissues. The transition to phloem-only supply at veraison in grape is accompanied by a change in unloading mechanism, from symplastic (via plasmodesmata), to one that includes an apoplastic step (Zhang et al., 2006). These two unloading types lead to differences in solute accumulation in the apoplasm (Patrick, 1997), which may affect sink water status, the flow of water in the xylem, and the composition of any xylem sap that returns to the plant (Matthews \& Shackel, 2005). The transition to apoplastic unloading occurs primarily in sinks that accumulate high 
concentrations of osmotically active solutes such as ripening grapes and tomatoes (Lalonde $e t$ al., 2003, Patrick, 1997) but has also been observed in some tissues of developing flowers (Werner et al., 2011). However, more research is needed to understand whether the form of sugar unloaded in the fruit (e.g. sucrose, sugar alcohols and raffinose, which are tied to different loading strategies) has important implications for fruit development.

By combining our knowledge of flowers and fruit, a model emerges of highly regulated changes in phloem and xylem functioning, coordinated with each stage of reproductive development. The phloem contribution to hydration is expected to increase with decreasing phloem sap concentration, organ transpiration and fresh weight growth, and with increasing carbon requirements for nectar or storage. However, more research is need to determine the extent that the balance between the two vascular tissues differs between species, environments and functional groups, and whether hydraulic isolation in reproductive organs is favored in warmer and drier environments, or in taxa that accumulate high levels of osmotically active solutes in their petals or ovaries. Just as changes in xylem functioning have had a major role in the evolution of terrestrial plants (Boyce et al., 2009, Sperry, 2003), the properties of the phloem may have constrained angiosperm reproductive evolution in ways that we have only just begun to understand.

\section{CARBON FLUXES IN PLANTS AND ECOSYSTEMS}

Models of carbon allocation in trees and carbon cycling in ecosystems require information about the rate and size of carbon fluxes that occur in plants. Although several ecosystem (e.g., Duursma \& Medlyn, 2012, Friend, 1995, Mackay et al., 2012, Ogée et al.,

2003) and global scale vegetation models (e.g., Bonan et al., 2014, Hickler et al., 2006, Xu et al., 2012) consider the xylem on a mechanistic basis and model the entire soil-plant- 
atmosphere continuum, these same models rely on empirical carbon-transfer or partitioning schemes to understand carbon fluxes. A more mechanistic understanding of how canopy photosynthesis and transpiration fluxes are coupled to water and carbon use (including plant and soil respiration and phloem transport) and the factors that control changes in carbon allocation within plants would make it easier to model the rates of ecosystem carbon and water exchange and examine how sensitive surface fluxes will be to environmental forcing (McDowell et al., 2013, Migliavacca et al., 2011).

\section{What assumptions are made about phloem transport in tree carbon budgets?}

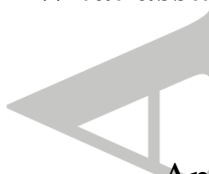

An annual carbon budget for a tree was first calculated, with limited compartment partitioning, by Tranquillini (1979) and by Ågren et al. (1980) using a mass balance approach. Although this type of analysis does not explicitly deal with the phloem, its estimates of carbon flux are based on assumptions about phloem transport. A realistic tree carbon balance needs to account for the dynamic nature of phloem transport and move beyond a simple 'black box' understanding of carbon flux ('black box' versus new carbon allocation model, Fig. 4). Here we highlight two critical aspects of phloem transport that have important implications for whole plant carbon balances: the variety of carbon sources that exist in the plant and the possibility of flow in multiple directions (not exclusively from the leaves to the roots).

Carbon supply via photosynthesis is sensitive to multiple factors such as light, temperature, and tissue hydration, and hence the availability of fresh assimilates for various plant processes is often interrupted. Carbon reserves, mainly in the form of nonstructural carbohydrates (NSC), have been long recognized as a major tool used by plants to bridge carbon supply interruptions (Hoch et al., 2003, Richards \& Caldwell, 1985, Schnyder, 1993). 
For example, deciduous trees in temperate forests shed their leaves before the dormant season, during which carbon reserves are the sole source for a 'baseline' maintenance respiration. The role of NSC as a carbon source further increases toward spring, when new growth takes place before leaves are fully expanded and active. Similarly, tree species in Mediterranean and semi-arid forests are compelled to close their stomata during a long dry season, and hence must rely on NSC as a carbon source (Hoch et al., 2003, Schadel et al., 2009).

A comprehensive and validated carbon allocation partitioning that considers NSC as a potential carbon source was recently calculated for mature pines (Pinus halepensis Miller) growing in a semi-arid forest (Klein \& Hoch, 2015). In those trees, the seasonal dynamics in the whole-tree starch content were dominated by large fluctuations in the stem and root starch pools. More than half of each of these pools was degraded and consumed during the transition from wet to dry season, indicating the important role of starch as a carbon source for plant activities outside leaves. When expressing the NSC as pool sizes, and accounting for the total foliage biomass compared to that of the woody compartments (above- and belowground), it becomes clear that non-leaf tissues play a major role in post-photosynthetic carbon supply. These results reinforce that fact that carbon loading into the phloem can take place at multiple sites along the transport pathway, depending on the availability of mobile carbon in adjacent cells.

Tree carbon balances also need to consider that the direction of phloem transport can change depending on source and sink activity. This can be seen in the aforementioned study on pines, where Klein and Hoch (2015) demonstrated that there were two relocation flows: carbon transport from roots to the stem, and from the stem to the leaves (Fig. 4). These flows were relatively minor in size (ca. $5 \%$ of the maximum wet season transport flux), and restricted to the drought months of July and August. The potential carbon relocation to the 
leaves in July correlated with a minimum in the foliage starch pool, while the stem starch pool was also close to its lowest level. This stem to foliage relocation suggests some low threshold level at which local starch hydrolysis stops and carbon must be imported into leaves, in agreement with Hoch (2005). Root to stem relocation might suggest that carbon transport within the tree is governed by sink activities rather than supply level, as discussed in earlier studies (Farrar \& Jones, 2000).

Despite growing interest in understanding patterns of carbon allocation within plants, relatively few studies have attempted to make a direct connection between carbon allocation and phloem transport (but see Nikinmaa et al., 2013, Schiestl-Aalto et al., 2015, Woodruff \& Meinzer, 2011). However, our view of carbon allocation might change as we learn more about phloem physiology, the significant role of NSC as an intrinsic carbon source, the major role of respiration among the different carbon sinks, the possibility of bidirectional carbon flows, and the existence of other carbon transport systems, e.g. via the ray and axial parenchyma or the xylem (Améglio et al., 2002, Sauter, 1982, Schill et al., 1996). Future experiments considering the dynamic nature of phloem transport will allow us to better understand to what extent relocation flows can change (e.g. increase under environmental stress), whether such carbon management changes offer any advantage to tree fitness and drought resistance, and the implications of carbon storage to forest ecology, biomass production and ecosystem function.

\section{How do tall trees transport carbon?}

Many aspects of ecosystem function, plant growth and productivity are influenced by plant size including carbon storage, canopy transpiration and plant water usage (e.g., Falster et al., 2011, Feldpausch et al., 2012, McDowell et al., 2011). As a plant grows, it can gain 
better access to water and light by increasing the footprint of its canopy and root system, but it also has to invest more resources in structural and supportive tissues. At the same time, it experiences more negative water potentials, lower hydraulic conductivity and lower stomatal conductance in its canopy. These and other observations have led to many hypotheses about what limits plant height from hydraulics to the growth of non-photosynthetic tissue (e.g., Givnish, 1995, Givnish et al., 2014, King, 1991, Ryan et al., 2006, Ryan \& Yoder, 1997) and to research on the impact of plant height on vascular transport (e.g., McCulloh et al., 2003, Mencuccini, 2002, West et al., 1999). However, until recently, most of the research concerning height-related constraints on transport has focused on the xylem despite the important implications of plant height on both parts of the vascular system.

Earlier modelling by Tyree et al. (1974) concluded that transport in sieve tubes as long as $50 \mathrm{~m}$ was possible in angiosperms, provided that sieve tube conductivity increased relative to values in shorter tubes and that sap velocity decreased closer to the sink, as a result of sucrose unloading and consumption along the transport path. The main effect of increasing sieve tube conductivity in longer tubes (i.e., taller trees) was to decrease the pressure and concentration gradients required to sustain vertical flow, which in turn required relatively high sucrose concentration. More recently, Thompson \& Holbrook (2003) relaxed several assumptions of earlier models and coupled phloem transport to changes in water potential of the surrounding tissue. They showed that under many conditions, water potential equilibrium between xylem and phloem was satisfied, and carbon transport could occur from sources to sinks in an osmotically regulated fashion (see section on CARBON-WATER INTERACTIONS). However, in this model, the behavior of the sieve tube is strongly dependent on tube radius and length, such that in a very long tube (tens of meters) significant declines in phloem turgor are predicted to occur, potentially impairing carbohydrate transfer in tall trees (Thompson 2006). 
How do plants cope with the challenge of long-distance transport in the phloem? The system modelled by Thompson and Holbrook (2003) is that of a single untapered and unbranched tube with sieve plates and a semi-permeable membrane. However, similar to the situation for the xylem (e.g., Tyree \& Ewers, 1991), the conductivity of a single pipe is only one of a number of factors affecting the efficiency of hydraulic transport at the organismal scale. While we still do not have a clear understanding of the relative contribution of all the possible components, one can speculate that many factors influence carbon transfer efficiency and reduce resistance along the transport pathway. Some of these factors include the progressive widening of sieve element diameters, the lengthening of the sieve elements which will increase the mean distance between sieve plates, the decrease in conduit frequency and density, and the decrease in phloem area relative to xylem area towards the base of the plant (e.g., Hölttä et al., 2009, Jyske \& Hölttä, 2015, Mencuccini et al., 2011, Petit \& Crivellaro, 2014, Woodruff, 2014). Additionally, the ratio of total phloem conducting area to the leaf area of the plant will affect whole-plant sugar loading and plant water potential (Hölttä et al., 2009, Mencuccini et al., 2011).

The effects of gravity on axial phloem transport and on the scaling of phloem anatomy with plant size have generally not been considered carefully in tall plants despite the analytical solutions that exist for both xylem and phloem transport (Jensen et al., 2011, McCulloh \& Sperry, 2005, West et al., 1999) and the more complex simulation models of allometric scaling developed based on optimality principles (e.g., reviewed in Mencuccini et al., 2011). Gravity can impact phloem transport in two very different ways, i.e., a) by affecting turgor at the top of tall plants (and therefore the realized cell size as a consequence of the effects of turgor on cell growth) and b) as an additional force that affects the movement of a solution along a vertical axis. Effect a) impacts the scaling of both xylem and phloem 
conductance as a consequence of parallel changes in apical cell diameters. Effect b) hinders the upward pull in the xylem and phloem but helps transport of carbon towards the roots.

While much progress has been made in elucidating mechanisms of phloem loading and unloading, questions about the physical organization of this vertical superhighway, and the significance of plant height for phloem transport, have not been explored thoroughly. We still lack a sound understanding of how environmental factors affect these anatomical and morphological traits, how this set of characters relates and trades off against other sets of plant traits, and how these strategies combine and vary across evolutionary lineages to affect carbon transfer at the ecosystem scale.

\section{How does phloem physiology influence the rate of carbon transfer to the soil?}

Plant carbon use has large scale implications for ecosystem function because of the role that plants serve in carbon sequestration (Barford et al., 2001), their role in food webs (Elser et al., 2000) and their influence on belowground respiration through root metabolism, interactions with soil microbiota and production of litter (Fig. 1, Cornwell et al., 2008, Högberg et al., 2001, Jones et al., 2009). Plants transfer carbon belowground by two pathways, i.e., via the detritus formed by leaf and root litter and by mass transport in the phloem (see next section on BIOTIC INTERACTIONS). The detritus feeds heterotrophic organisms (predominantly fungi and bacteria) and is therefore primarily responsible for the dynamics of carbon stocks present in soils and litter layers (e.g. Malhi et al., 1999). Typically, the timescale for the production of this detritus is in the order of years to decades. Conversely, carbon transfer by the plant phloem, which is primarily employed to sustain root growth, carbohydrate storage and 'autotrophic' respiration belowground, occurs over shorter 
time scales (cf., Högberg \& Read, 2006, Janssens et al., 2001) and may change more rapidly in response to environmental conditions.

Continuous measurements of soil $\mathrm{CO}_{2}$ efflux and vertical soil $\mathrm{CO}_{2}$ profiles, coupled with measurements of canopy photosynthesis by eddy covariance, have allowed the exploration of the diel and seasonal dynamics of the links between carbohydrate production and consumption by (autotrophic and heterotrophic) respiration in the field (reviewed by Vargas et al., 2011b). For example, Vargas et al. (2010) showed that the timing of soil $\mathrm{CO}_{2}$ production was temporally coherent with changes in soil temperature and photosynthetically active radiation (PAR, used as an indicator of photosynthesis). In a second study, they found a significant temporal synchrony between canopy photosynthesis and soil $\mathrm{CO}_{2}$ efflux at a one day time scale or longer, suggesting that these two fluxes were closely coupled and that there is very fast transmission of information about the state of the canopy to the root-soil system (Vargas et al., 2011a). This evidence suggests that phloem transfer of carbohydrates belowground is directly linked to canopy photosynthesis, and it is sufficiently fast that diurnal and seasonal changes in weather conditions which impact ecosystem-scale photosynthesis are quickly perceived as changes in ecosystem respiration, thereby creating a feedback with the carbon balance of the site.

Another approach used to determine the significance of phloem transfer to carbon cycling has been to curtail this transfer directly, either by root trenching (cf., Hanson et al., 2000), phloem girdling (cf., Andersen et al., 2005, Bhupinderpal-Singh et al., 2003, Binkley et al., 2006, Högberg et al., 2001, Scott-Denton et al., 2006, Subke et al., 2004) or transient bark chilling (Johnson et al., 2002). However, most of the information on the variables controlling the transfer of carbohydrates belowground at seasonal to multi-year time scales has been obtained using isotopic techniques (for reviews, see Kayler et al., 2010, Kuzyakov \& Gavrichkova, 2010, Mencuccini \& Hölttä, 2010a, Mencuccini \& Hölttä, 2010b). These 
approaches have been advanced considerably by the use of new technologies such as fastresponse laser absorption spectrometry or cavity ring-down spectroscopy. Using the latter approach, Dannoura et al. (2011) found differences among species in their isotopicallydetermined velocities, which were found to depend on the mean air temperature for the 24 hours following labelling. In general, isotopic studies have found lags of around one to five days or longer for the times taken by the isotope peaks to appear as either stem or soil $\mathrm{CO}_{2}$ efflux, with the lag dependent on plant height following a power law relationship (Mencuccini \& Hölttä, 2010b). The shape of this relationship is consistent with the occurrence of a reasonably constant phloem turgor gradient across species spanning 50m of height range, with a positive scaling of mean phloem specific conductivity with plant height (see second subsection in CARBON FLUXES IN PLANTS AND ECOSYSTEMS). This means that both the transport rate of the phloem and the architecture of trees could have important implications for carbon cycling.

At longer time scales (seasonal to multi-annual), the task of determining the ecological significance of phloem transport is made easier by recognizing that a different set of constraints can be imposed on the problem. In general, the rate of carbohydrate flux must be equivalent to canopy photosynthetic flux, the net of the fluxes going into and coming out of intermediate storage pools and sinks present along the transport pathway (see previous subsection). This inventory approach can also be extended to incorporate the carbon fluxes to the soil. Giardina \& Ryan (2002) devised a simple mass balance approach based on a water tub analogy to work out the total belowground carbon allocation (TBCA) from measurements of aboveground fluxes of detritus, changes in pool sizes belowground and gaseous $\left(\mathrm{CO}_{2}\right)$ and liquid (dissolved inorganic and organic carbon) losses by the soil. Using this method over typical intervals of one to several years, one arrives at reasonable estimates of phloem fluxes belowground. This approach is useful for comparisons carried out at yearly to decadal time 
scales to investigate responses to ecological processes such as nutrient availability, inter-plant competition or stand development. One significant finding of this and similar studies is that TBCA can be a large fraction of gross photosynthesis (up to 60\%) and that it can change dramatically as a function of tree size and stand development (Giardina \& Ryan, 2002, Zerva et al., 2005). For example, Giardina et al. (2014) looked at a vertical elevation gradient in a tropical montane wet forest and found that stands at lower elevations (higher mean temperatures) circulated carbon belowground faster, both as aboveground detritus and as TBCA via phloem transfer.

Accurate models of belowground carbon transfer rely on a clear mechanistic understanding of the extent that phloem transport dominates carbon flux into the soil and how coupled carbon transport is to changes in environmental conditions. However, at larger spatio-temporal scales, some of the processes and trade-offs that relate to the short-term dynamics of phloem loading, transport and unloading lose their relevance, while others continue to maintain their significance. A more thorough understanding of phloem physiological ecology will help identify which traits should be explored in more detail to evaluate their long-term ecosystem-scale significance.

\section{BIOTIC INTERACTIONS}

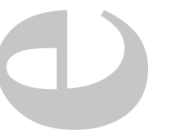

Where and when plants allocate carbon to different organs can influence their interactions with other organisms (e.g., Elzinga et al., 2007, Tiffin, 2000) but the role of carbon transport in mediating biotic interactions involves more than structural investment. Many carbon-rich compounds from nectar to secondary compounds help plants attract beneficial and deter detrimental organisms (Bekaert et al., 2012, De la Barrera \& Nobel, 2004, Gershenzon, 1994, Pichersky \& Gershenzon, 2002). Some of these compounds are 
transported in the phloem while others are made from nutrients or their production is regulated by signals delivered by this vascular tissue (Heil \& Ton, 2008, Turgeon \& Wolf, 2009). In fact, approximately $40 \%$ of the net carbon fixed by plants is transported in the phloem to roots (Jones et al., 2009) where a large portion is exuded into the soil and supports many soil organisms (Hartmann et al., 2009). In this section, we discuss how the phloem influences plant interactions with a few important components of their biotic environment: pests, pathogens, and soil microorganisms.

\section{How does phloem physiology shape plant-pest interactions?}

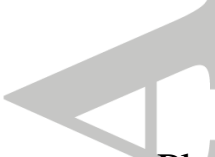

Plants live under a continuous threat from insects, herbivores and pathogens, and have evolved mechanisms to minimize the negative impact of these organisms, including the development of physical and chemical defenses (Futuyma \& Agrawal, 2009). Because these defenses require energy and resources for their production, maintenance and in the case of some compounds their transport (Bekaert et al., 2012, Gershenzon, 1994), many researchers have proposed that investing in defense can come at the expense of other types of growth (Bazzaz, 1987, Coley et al., 1985, Herms \& Mattson, 1992). This "cost" is the basis of multiple plant defense theories that are used to explain the diversification of secondary metabolites and the relationship between fitness, defense and resource availability (for review, see Stamp, 2003). However, when defense is considered in the context of phloem transport (Fig. 1), the situation becomes more complicated because of constraints that vascular architecture and source-sink relationships place on plant defense responses (Arnold et al., 2004, Honkanen et al., 1999, Jones et al., 1993, Larson \& Whitham, 1991, Orians, 2005, Schultz et al., 2013). 
The phloem is responsible for transporting many secondary metabolites, including alkaloids, flavonoids and glucosinolates, along with resources and informational signals required for the biosynthesis of these and other defense compounds (for reviews, see Heil \& Ton, 2008, Turgeon \& Wolf, 2009). In the case of constitutive defenses, those which are not activated by wounding or infection, the phloem primarily serves as a transport system for establishing pools of secondary metabolites. However, in the case of inducible defenses, source-sink relationships can determine the intensity and location of a defense response (for reviews see Orians, 2005, Schultz et al., 2013). Wounded and infected tissues often receive an influx of carbon from the phloem, a response that appears stimulated by enzymatic breakdown of sugars (Arnold \& Schultz, 2002, Berger et al., 2007, Rosenkranz et al., 2001, Zhang et al., 1996) and/or changes in sucrose transporter activity (Meyer et al., 2004). This response can be triggered by herbivory, infection and plant defense elicitors, including jasmonic acid (Arnold \& Schultz, 2002, Walters \& McRoberts, 2006), and is linked with the production of phenolics in leaves, including condensed tannins (Arnold et al., 2004, Ferrieri et al., 2012). Because the induction of these defenses is tied to phloem transport, young leaves that are active sinks accumulate higher levels of phenolics than adjacent sources leaves (Appel et al., 2012, Arnold et al., 2004), and root herbivory can induce a defense response in both above- and belowground sinks (Kaplan et al., 2008).

Plants employ many strategies to resist pests in addition to chemical defenses, some of which are tied to whole-plant shifts in resource allocation (Tiffin, 2000). For example, many species exhibit compensatory growth in response to herbivory, i.e. faster growth, higher rates of photosynthesis in unattacked leaves and/or dormant meristem activation (Lebon et al., 2014, McNaughton, 1983, Nowak \& Caldwell, 1984). Research also suggests that some plants may increase carbon and nitrogen transport into their roots in response to aboveground herbivory, a process often referred to as "sequestering" or "bunkering" that relies directly on 
phloem transport (Babst et al., 2005, Gómez et al., 2010, Holland et al., 1996, Schwachtje et al., 2006). This response could be advantageous if stored resources aid in re-foliation and resprouting (Orians et al., 2011). Considering the challenges that exist in comparing different defense and tolerance strategies, it is not surprising that there is debate about whether changes in carbon allocation are always adaptive (Tiffin, 2000). Regardless of this point, research on growth responses to herbivory demonstrates the extent that source and sink relationships in plants can be altered by pests.

The majority of pests that attack plants do not directly interact with the phloem but there are three important exceptions: phloem-feeders (e.g. aphids, leafhoppers and whiteflies), parasitic plants (e.g. Cuscuta, L.) and phloem-mobile pathogens. Central to the success of phloem feeders is their ability to insert their stylets into living sieve elements without triggering a wound response in the penetrated cell. Some have argued that this is a result of calcium binding proteins in their watery saliva (Will et al., 2009, Will \& van Bel, 2006) but the evidence for this is still under debate (Knoblauch et al., 2014). Once these insects have established a connection with their host, they begin to consume phloem sap and can readily transfer phloem-mobile diseases. Diseases can also be transferred by parasitic plants that establish symplastic connections with their host's phloem (Birschwilks et al., 2006). Because phloem-feeders and parasitic plants create phloem sinks (Peel \& Ho, 1970), their access to resources is influenced by vascular connectivity and the presence of other pestand plant-based sinks. For example, Larson and Whitham $(1991,1997)$ showed that that galling aphids are less successful at establishing near flowers, which are strong carbon sinks, and on plants with a lower source-to-sink ratio (e.g. lower ratio of stem volume to buds). There is also evidence that adjacent galls can either have negative or positive effects on each other depending on the carbon requirements of each structure and their arrangement on a leaf (Heard \& Buchanan, 1998, Inbar et al., 1995). 
There is growing evidence that plant community assembly and larger patterns of diversity are impacted by herbivores and pathogens (Connell, 1971, Fine et al., 2004, Janzen, 1970, Webb et al., 2006). However, the literature on plant-pest interactions and defense trade-offs is full of conflicting observations, both in terms of where carbon moves in response to wounding and whether there are "costs" associated with different defense responses. Critical to sorting out these discrepancies is research examining source-sink relationships and vascular architecture, which will help us understand the costs to and constraints of different defense strategies (Appel et al., 2012, Kaplan \& Denno, 2007, Schultz et al., 2013). This type of research will inform our understanding of plant defense and the role of phloem physiology in mediating different aspects of plant-pest interactions.

\section{What is the phloem's role in rhizosphere interactions?}

Belowground ecological processes are critical to all stages of the lives of plants. Many of these processes, including root interactions with soils and soil biota, are controlled or influenced by photosynthates transported to root tissues. When analyzed in terms of carbon products, rhizodeposition, the releasing of organic compounds by roots into the soil, may account for $30-90 \%$ of root carbon allocation (Nguyen, 2003, Whipps, 1990). This occurs by different mechanisms, such as releasing mucilage, exudates, secretions and border cells, through cell death (senescence), and by direct carbon flow to mycorrhizal and bacterial mutualists (Jones et al., 2009). Rhizodeposition also elicits changes in soil organic matter decomposition, an effect known as rhizosphere priming, which is highly influential in soil carbon dynamics and affects the supply of nutrients to plants (Dijkstra et al., 2013) along with stimulating growth in the rhizosphere (Meier et al., 2012). With such large quantities of carbon being allocated to plant roots and the strong links that exist between plant phenology, 
changes in carbon allocation and soil respiration (Cardon et al., 2002, Davidson \& Holbrook, 2009), the role of phloem in root carbon dynamics cannot be understated (Fig. 1).

The rhizosphere is inhabited by large populations of bacteria and fungi that form a broad array of associations with plants, from mutualistic to pathogenic. These organisms typically rely on plants for carbon and other resources which they access using different methods. For example, some organisms directly modify plant phloem, including rhizobacteria that produce hormones such as auxins and cytokinins (Costacurta \& Vanderleyden, 1995), which are critical in controlling root vascular patterning, or enzymes that decrease ethylene production leading to higher fluxes of nutrients and carbon to the roots (Jiang et al., 2012). In contrast, nematodes cause the formation of new cells (feeding cells) adjacent to phloem, and which are highly vascularized subsequent to formation (Absmanner et al., 2013). In the case of cyst nematodes, these feeding cells are symplastically connected to adjacent sieve elements and companion cells by plasmodesmata (Absmanner et al., 2013, Bartlem et al., 2013).

A wide range of interactions also occur between mutualistic bacteria and mycorrhizal fungi, and their plant hosts. These symbiotes rely on plants for carbohydrates and protection and, in exchange, they enhance plant nutrient acquisition or, in the case of nitrogen-fixing bacteria (rhizobia), provide biologically available nitrogen to the host. With mycorrhizal associations, the fungi do not access carbon by directly tapping into the phloem; instead the hyphae either extend into cortical cells or are confined to the root epidermis, as observed in arbuscular mycorrhizae and ectomycorrhizal and ericoid hyphae, respectively (Peterson \& Massicotte, 2004). While there has been significant research into how plants modify their cells and membranes to accommodate and exchange resources with hyphae, it remains unclear if the fungi modify plant vasculature and phloem unloading. 
In the case of rhizobia, carbon is transferred to the symbiotes from the phloem through transfer cells and companion cells in the nodule that symplastically connect sieve elements to infected tissues (Joshi et al., 1993, Peiter \& Schubert, 2003). Because the phloem helps hydrate nodules, it has been hypothesized that changes in phloem turgor may impact nodule gas permeability, and thus provide a mechanism for plants to limit resource delivery to rhizobia during periods of drought (Walsh, 1990, Walsh, 1995). Other work suggests that feedback mechanisms may lower nodule activity when water limits nitrogen export (Serraj et al., 1999) or that phloem-mobile signals regulate these processes (Parsons et al., 1993, Sulieman \& Schulze, 2010, Sulieman \& Tran, 2013) but the exact nature of these feedbacks remains unresolved.

Soil microbes and organisms interact with plants both directly by modifying phloem structure and function, as described above, and also indirectly through other organisms that rely on the same hosts. For example, rhizobacteria can influence phloem-feeding insect performance on the same plant (Shavit et al., 2013), and phloem feeding insects can attract rhizobacteria to plant roots (Lee et al., 2013). Recent work also demonstrates that soil microbes and symbiotes like rhizobia can influence organisms aboveground by reducing extrafloral nectary production (Godschalx et al., 2014). Connections like these demonstrate that the phloem could have a role in facilitating communication and resource competition between above- and belowground organisms (Griffiths et al., 2007).

The phloem mediates bi-directional interactions between soil biota and plants: soil organisms impact carbon allocation by changing plant vascular structure and acting as sinks, and plant rhizodeposition exhibits a large degree of control over rhizosphere microbial populations. Both of these processes can have downstream effects on food webs (Way, 1963) and carbon cycling (see previous section on CARBON FLUXES IN PLANTS AND ECOSYSTEMS). Despite the importance of phloem in these and other belowground 
processes, fundamental knowledge gaps in areas such as signaling and the control of apoplastic versus symplastic flow in plant-organism symbioses will keep the mechanisms behind these processes in a black box until their secrets are revealed.

\section{PHLOEM LOADING, A CASE STUDY: WHAT PHYSIOLOGISTS CAN LEARN BY THINKING ABOUT ECOLOGY}

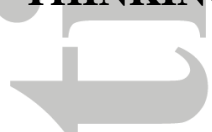

In this review, we have discussed the importance of considering phloem transport when studying plant physiological ecology, but research on phloem physiology can also benefit from examining differences in plant function in the context of evolution. This type of research can help us consider the costs and benefits of different physiological strategies, a point that is well demonstrated by recent work considering the ecological implications of phloem loading type in angiosperms.

In the source tissue, carbon is loaded into the phloem by one or a combination of three mechanisms (Fig. 5). In passive loading, sucrose migrates symplastically from mesophyll cells to sieve tubes down a concentration gradient (Reidel et al., 2009, Rennie \& Turgeon, 2009, Turgeon \& Medville, 1998, Zhang et al., 2014). A less common symplastic mechanism involves synthesis of raffinose and stachyose in specialized companion cells (intermediary cells) and is termed polymer trapping because it "traps" sugar in the phloem on the basis of molecular size (Dölger et al., 2014, Zhang et al., 2014). The third mechanism, apoplastic loading, was the first to be discovered (Geiger et al., 1971) and is the most common strategy in crop plants. Apoplastic loading involves efflux of sucrose into the cell wall space and subsequent active uptake into the phloem by symport with protons (Braun et al., 2014).

It is currently believed that gymnosperms load passively (Liesche et al., 2011) and that passive phloem loading is ancestral in angiosperms (Turgeon et al., 2001). Passive 
loading is, with few exceptions, used primarily by trees (Rennie \& Turgeon, 2009) and active loading is more common in herbs and a restricted number of woody species. Recent work suggests that trees may not require an active loading step because they often maintain high concentrations of leaf sugars to offset low whole-plant hydraulic conductance in the xylem (Fu et al., 2011). The elevated sugar content in the leaves apparently provides enough foliar sucrose to drive phloem transport by Münch pressure flow and removes the need for thermodynamically active loading. It has also been suggested that loading strategies are correlated with climate (Gamalei, 1989) but this appears to be due to the virtual absence of trees, and therefore passive loading, in very cold climates, not a direct effect of temperature on loading (Davidson et al., 2011).

Given the almost complete absence of passive loading in herbs and the fact that active loading is an evolutionarily derived trait, what are the advantages of active loading? It is difficult to argue that energy must be expended in the loading step to drive long-distance transport efficiently since many trees, with much longer transport distances than herbs, seem to do without it (Turgeon, 2010b). Even so, high solute concentration in the phloem, and the elevated hydrostatic pressure it generates, could be advantageous for other reasons, including coordinated regulation of loading and unloading at distant sites (Fisher, 2000, Patrick, 2013), wound healing (Knoblauch \& Mullendore, 2012), discouraging phloem feeders, which cannot tolerate high osmotic potentials (Turgeon, 2010a) and optimizing viscosity for transport (Jensen et al., 2013). Another advantage is that active loading allows the plant to reduce overall sucrose levels in leaves and still generate the phloem pressure needed to drive longdistance transport (Turgeon, 2010b). Reducing sucrose inventory frees up carbohydrates, which are needed to foster growth of new leaves. Following the compound interest law, the more efficiently new leaves are produced, the faster the overall relative growth rate of the plant. As a result, it is possible that phloem loading explains part of the variation observed in 
the leaf economic spectrum and has larger implications for plant growth strategies and species distributions (Reich, 2014, Wright et al., 2004).

Although this could help explain the widespread adoption by active loading in herbs, it does not explain why some species accomplish this by polymer trapping while others load through the apoplast. One explanation for the evolution of polymer trapping could be that it allows other important compound(s) besides sucrose to enter the phloem symplastically. For example, in certain families that load by polymer trapping, iridoid glycosides, anti-microbial and anti-herbivore compounds are phloem mobile and are approximately the same molecular size as sucrose (Gowan et al., 1995, Lohaus \& Schwerdtfeger, 2014, Turgeon \& Medville, 2004, Voitsekhovskaja et al., 2009).

The concept of symplastic loading in general has been criticized on the grounds that a continuous plasmodesmatal pathway would allow ions and small molecules to enter the phloem from the mesophyll non-selectively (Lucas et al., 2013). However, selectivity is not as fundamental a property of phloem transport as is often assumed. Sieve tubes transport a wide range of ions and compounds in concentrations similar to those of other plant cells (Winter et al., 1992). Indeed, ions and small molecules continuously leak into the sieve tubes through the plasmodesmata that connect companion cells to their adjacent sieve tubes. Another limitation imposed by polymer trapping and passive loading, is that up-regulation of loading capacity requires the placement of additional plasmodesmata, which does not occur in mature leaves, thus restricting the response to increased light availability (Amiard et al., 2005). Instead, these plants acclimate to high light by growing new leaves with higher vein densities.

Understanding the adaptive advantages and disadvantages conferred by different loading mechanisms will shed light on the complex role phloem transport plays in growth, and plant responses to the biotic and abiotic environment. Because of the impact of loading 
type on both the osmotic potential of leaf mesophyll cells and the form of sugar transported in the phloem, it could also have important implications for other aspects of plant physiology ranging from leaf hydraulics to fruit development (see earlier section on CARBON-WATER INTERACTIONS) that have yet to be explored. Further research testing the hypotheses laid out in this section will help us better understand the complex evolutionary processes that have shaped the diversification of phloem loading and other aspects of phloem physiology.

\section{CONCLUSIONS AND FUTURE DIRECTIONS}

As the primary delivery system for carbon inside the plant, the phloem serves a critical role in mediating shifts in carbon allocation and growth that influence how plants interact with the environment and how they impact local food webs and carbon cycling (Fig.

1). However, this is only one of the many ways that phloem physiology influences plant ecology. Because of its tight hydraulic connection with the xylem, the phloem can influence drought tolerance and reproduction in ways we are only starting to understand. However, despite the often central role the phloem plays in many plant-environment interactions, there is limited research considering its role in plant physiological ecology.

In this review, we highlight research that integrates phloem physiology and plant ecology by focusing on carbon-water interactions, carbon fluxes in plants and ecosystems, and biotic interactions. The material presented is by no means comprehensive and there are many other ecologically important aspects of plant physiology that could be influenced by the phloem including phenological changes that occur in response to phloem-mobile signals (Haywood et al., 2005, Turck et al., 2008, Turnbull, 2011), production of isoprene and other organic volatile compounds (Kerstiens \& Possell, 2001, Logan et al., 2000), and the transport of nitrogen and amino acids (Tegeder, 2014). However, the goal of this review is not to 
address all of the pertinent literature but to draw attention to the critical nature of research that lies at the interface between phloem physiology and ecology. Going forward, it is crucial that we increase our understanding of phloem function and develop a robust framework for considering the ecological and evolutionary implications of phloem physiology. To achieve these goals, there are four critical areas of research that we believe need to be pursued in the

\section{future.}

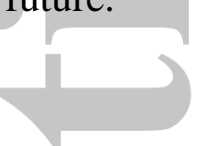

(1) Trade-offs in the phloem - A central pursuit of physiological ecology is to understand the costs and benefits of different physiological strategies and determine how trade-offs impact plant performance. Unfortunately, many of the trade-offs that influence phloem structure and function are poorly understood. For example, a high level of symplastic continuity in the leaf is considered advantageous because it would minimize the need to actively transport secondary compounds and informational signals across membranes. However, as pointed out earlier, many species use active loading mechanisms (Turgeon, 2010b). Is there a trade-off between fast growth strategies associated with active loading and efficient long-distance communication? Within a flower, there is variation in how symplastically connected individual organs are with the phloem (Werner et al., 2011). Are there costs and benefits of these differences? Research aimed at answering these questions and clarifying the relationship between phloem structure and function will help advance our understanding of different physiological strategies and thus provide a more robust framework for thinking about phloem evolution.

(2) Xylem-phloem coupling - There is a large body of work linking plant hydraulics and xylem function to species distributions and investigating the ecological implications of xylem form and function (e.g. Hacke \& Sperry, 2001, Jacobsen et al., 2007, Preston et al., 2006). 
Less attention has been paid to phloem but the structural and physiological connections that exist between these two tissues, some of which may be governed by critical trade-offs, suggest it could be equally influential in defining plant-environment relationships. Interactions between the xylem and phloem are especially important in sink tissue (e.g. flowers and fruit) where high osmotic gradients can alter the water balance of these two tissues (e.g. backflow in the xylem). Further investigation focusing on the interaction between the two vascular systems is likely to yield novel insights into the integration of plant functional properties and their significance for plant ecology by providing a unique perspective on plant structure and function that is not found if the two systems are studied separately.

(3) Environmental plasticity - Climate change and increasing levels of $\mathrm{CO}_{2}$ appear to have a significant effect on the growth and survival of many species (Nemani et al., 2003) but little research has tried to investigate the impact of these conditions on phloem transport or vascular architecture. Considering that phloem integrates changes that happen in both source and sink tissue, could changes in the phloem partially explain shifts in carbon allocation that are observed in $\mathrm{CO}_{2}$ addition experiments? Do plants with different loading types exhibit altered responses to elevated $\mathrm{CO}_{2}$ ? How do seasonal changes in the phloem impact plant phenology and broader sets of traits that impact species distributions? Research on these and related questions will allow us to better understand phloem plasticity and how it might impact plant carbon allocation and stress tolerance.

(4) Ecosystem-scale significance of phloem transport - Do physiological properties of phloem transport have importance at higher levels of organization, especially in relation to ecosystem-scale fluxes of carbohydrates and plant-soil interactions? Some authors (Kayler et 
al., 2010, Kuzyakov \& Gavrichkova, 2010) have proposed that phloem transport may be a bottleneck in the link between photosynthesis and belowground respiratory fluxes and that the observed ecosystem-scale relationships between photosynthesis and respiration are mediated by phloem-dependent traits. To what degree does the mass flux of sucrose in the phloem vary as a function of time of day, environmental conditions and seasonality? Can the changes in phloem physiology alter carbon supply and demand at the whole-organismal scale? These questions have implications for understanding and predicting the controls not only of autotrophic plants but also of the heterotrophic organisms that depend on this flux.

The phloem serves as part of an integrative vascular network that allows plants, as modular organisms, to respond on a larger scale to their environment through processes that we are only beginning to understand (Knoblauch \& Oparka, 2012, Turgeon, 2010a, van Bel, 2003). One of the main challenges for physiologists going forward is to develop methods that will allow us to better characterize the phloem and facilitate the collection of data on a larger variety of species. Although this has been a major limiting factor in the field of phloem physiology in the past, there have been many promising advances in recent years (Cayla et al., 2015, Knoblauch et al., 2014, Mullendore et al., 2010, Savage et al., 2013, Windt, 2007).

With continued work in this area, we can open new opportunities to examine the evolution of phloem anatomy and consider phloem in a more rigorous ecological and evolutionary framework. 


\section{ACKNOWLEDGEMENTS}

We acknowledge two anonymous reviewers, G. Hoch (University of Basel) and N. M. Holbrook (Harvard University) for providing thoughtful comments and feedback on the manuscript and T. Arnold (Dickinson College) for his involvement in the symposium that led to this review. Funding was provided by the Katharine H. Putnam Fellowship in Plant Science at the Arnold Arboretum (Savage); MBIE C06X0706, University of Waikato and Plant and Food Research (Clearwater); Plant Fellows (Klein) - an international Postdoc Fellowship Program in Plant Sciences of the Zürich-Basel Plant Science Center; NERC NE/I017749/1 (Mencuccini); Los Alamos National Laboratory LDRD-ER program (Sevanto) and the National Science Foundation - Integrative Organismal Systems Grant, No. 1354718 (Turgeon), Research was co-funded by the National Science Foundation - Integrative Organismal Systems Grant, No. 1021779 (Holbrook) and the EU FP7 Marie Curie actions and the Swiss National Fund project FORCARB (31003A_14753/1) allocated to the Basel Plant Ecology (Körner).

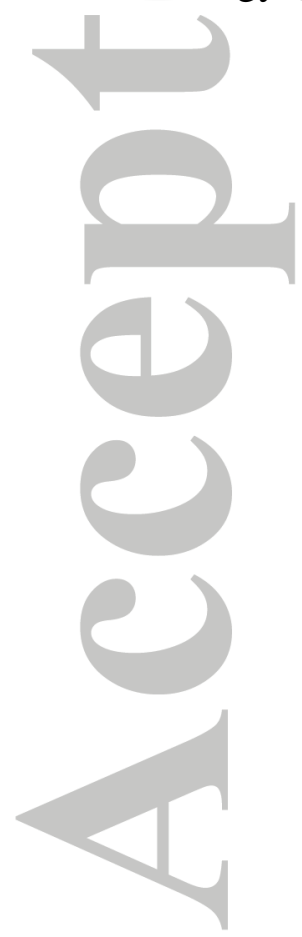




\section{REFERENCES}

Absmanner B., Stadler R. \& Hammes U.Z. (2013) Phloem development in nematode-induced feeding sites: the implications of auxin and cytokinin. Frontiers in Plant Science, 4.

Ackerly D. (2004) Functional strategies of chaparral shrubs in relation to seasonal water deficit and disturbance. Ecological Monographs, 74, 25-44.

Améglio T., Bodet C., Lacointe A. \& Cochard H. (2002) Winter embolism, mechanisms of xylem hydraulic conductivity recovery and springtime growth patterns in walnut and peach trees. Tree Physiology, 22, 1211-1220.

Amiard V., Mueh K.E., Demmig-Adams B., Ebbert V., Turgeon R. \& Adams W.W. (2005) Anatomical and photosynthetic acclimation to the light environment in species with differing mechanisms of phloem loading. Proceedings of the National Academy of Sciences of the United States of America, 102, 12968-12973.

Andersen C.P., Nikolov I., Nikolova P., Matyssek R. \& Häberle K.H. (2005) Estimating "autotrophic" belowground respiration in spruce and beech forests: decreases following girdling. European Journal of Forest Research, 124, 155-163.

Appel H.M., Arnold T.M. \& Schultz J.C. (2012) Effects of jasmonic acid, branching and girdling on carbon and nitrogen transport in poplar. New Phytologist, 195, 419-426.

Arnold T., Appel H., Patel V., Stocum E., Kavalier A. \& Schultz J. (2004) Carbohydrate translocation determines the phenolic content of Populus foliage: a test of the sinksource model of plant defense. New Phytologist, 164, 157-164.

Arnold T.M. \& Schultz J.C. (2002) Induced sink strength as a prerequisite for induced tannin biosynthesis in developing leaves of Populus. Oecologia, 130, 585-593. 
Babst B.A., Ferrieri R.A., Gray D.W., Lerdau M., Schlyer D.J., Schueller M., . . Orians C.M. (2005) Jasmonic acid induces rapid changes in carbon transport and partitioning in Populus. New Phytologist, 167, 63-72.

Barford C.C., Wofsy S.C., Goulden M.L., Munger J.W., Pyle E.H., Urbanski S.P., . . Moore K. (2001) Factors controlling long- and short-term sequestration of atmospheric CO2 in a mid-latitude forest. Science, 294, 1688-1691.

Bartlem D.G., Jones M.G.K. \& Hammes U.Z. (2013) Vascularization and nutrient delivery at root-knot nematode feeding sites in host roots. Journal of Experimental Botany, 65 , 1789-1798.

Bazzaz F.A. (1987) Allocating resources to reproduction and defense. Bioscience, 37, 58-67.

Bekaert M., Edger P.P., Hudson C.M., Pires J.C. \& Conant G.C. (2012) Metabolic and evolutionary costs of herbivory defense: systems biology of glucosinolate synthesis. New Phytologist, 196, 596-605.

Berger S., Sinha A.K. \& Roitsch T. (2007) Plant physiology meets phytopathology: plant primary metabolism and plant-pathogen interactions. Journal of Experimental Botany, 58, 4019-4026.

Bhupinderpal-Singh, Nordgren A., Löfvenius M.O., Högberg M.N., Mellander P.E. \& Högberg P. (2003) Tree root and soil heterotrophic respiration as revealed by girdling of boreal Scots pine forest: extending observations beyond the first year. Plant, Cell and Environment, 26, 1287-1296.

Binkley D., Stape J.L., Takahashi E.N. \& Ryan M.G. (2006) Tree-girdling to separate root and heterotrophic respiration in two Eucalyptus stands in Brazil. Oecologia, 148, 447454. 
Birschwilks M., Haupt S., Hofius D. \& Neumann S. (2006) Transfer of phloem-mobile substances from the host plants to the holoparasite Cuscuta sp. Journal of Experimental Botany, 57, 911-921.

Bonan G.B., Williams M., Fisher R.A. \& Oleson K.W. (2014) Modeling stomatal conductance in the earth system: linking leaf water-use efficiency and water transport along the soil-plant-atmosphere continuum. Geoscientific Model Development, 7, 2193-2222.

Bondada B.R., Matthews M.A. \& Shackel K.A. (2005) Functional xylem in the post-veraison grape berry. Journal of Experimental Botany, 56, 2949-2957.

Boyce C.K., Brodribb T.J., Feild T.S. \& Zwieniecki M.A. (2009) Angiosperm leaf vein evolution was physiologically and environmentally transformative. Proceedings of the Royal Society B-Biological Sciences, 276, 1771-1776.

Braun D.M., Wang L. \& Ruan Y.L. (2014) Understanding and manipulating sucrose phloem loading, unloading, metabolism, and signalling to enhance crop yield and food security. Journal of Experimental Botany, 65, 1713-1735.

Bull T.A., Gayler K.R. \& Glasziou K.T. (1972) Lateral movement of water and sugar acoss xylem in sugarcane stalks. Plant Physiology, 49, 1007-1011.

Cardon Z.G., Czaja A.D., Funk J.L. \& Vitt P.L. (2002) Periodic carbon flushing to roots of Quercus rubra saplings affects soil respiration and rhizosphere microbial biomass. Oecologia, 133, 215-223.

Cayla T., Batailler B., Le Hir R., Revers F., Anstead J.A., Thompson G.A., . . Dinant S. (2015) Live Imaging of Companion Cells and Sieve Elements in Arabidopsis Leaves.

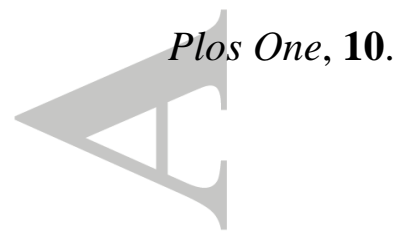


Chapotin S.M., Holbrook N.M., Morse S.R. \& Gutiérrez M.V. (2003) Water relations of tropical dry forest flowers: pathways for water entry and the role of extracellular polysaccharides. Plant, Cell and Environment, 26, 623-630.

Choat B., Gambetta G.A., Shackel K.A. \& Matthews M.A. (2009) Vascular function in grape berries across development and its relevance to apparent hydraulic isolation. Plant Physiology, 151, 1677-1687.

Clearwater M.J., Luo Z., Ong S.E.C., Blattmann P. \& Thorp T.G. (2012) Vascular functioning and the water balance of ripening kiwifruit (Actinidia chinensis) berries. Journal of Experimental Botany, 63, 1835-1847.

Clearwater M.J., Luo Z.W., Mazzeo M. \& Dichio B. (2009) An external heat pulse method for measurement of sap flow through fruit pedicels, leaf petioles and other smalldiameter stems. Plant, Cell and Environment, 32, 1652-1663.

Clearwater M.J., Ong S.E.C. \& Li K.T. (2013) Sap flow and vascular functioning during fruit development. Acta Horticulturae, 991, 385-392.

Coley P.D., Bryant J.P. \& Chapin F.S. (1985) Resource availability and plant antiherbivore defense. Science, 230, 895-899.

Connell J.H. (1971) On the role of natural enemies in preventing competitive exclusion in some marine animals and in the rain forest trees. In: Dynamics of Populations (eds P.J. Den Boer \& G. Gradweel), pp. 298-312, Wageningen.

Cornwell W.K., Cornelissen J.H.C., Amatangelo K., Dorrepaal E., Eviner V.T., Godoy O., . . - Westoby M. (2008) Plant species traits are the predominant control on litter decomposition rates within biomes worldwide. Ecology Letters, 11, 1065-1071.

Costacurta A. \& Vanderleyden J. (1995) Synthesis of phytohormones by plant-associated bacteria. Critical Reviews in Microbiology, 21, 1-18. 
Dannoura M., Maillard P., Fresneau C., Plain C., Berveiller D., Gerant D., . . Epron D. (2011) In situ assessment of the velocity of carbon transfer by tracing $13 \mathrm{C}$ in trunk $\mathrm{CO} 2$ efflux after pulse labelling: variations among tree species and seasons. New Phytologist, 190, 181-192.

Daudet F.A., Améglio T., Cochard H., Archilla O. \& Lacointe A. (2005) Experimental analysis of the role of water and carbon in tree stem diameter variations. Journal of Experimental Botany, 56, 135-144.

Davidson A., Keller F. \& Turgeon R. (2011) Phloem loading, plant growth form, and climate. Protoplasma, 248, 153-163.

Davidson E.A. \& Holbrook N.M. (2009) Is temporal variation in soil respiration linked to the phenology of photosynthesis? In: Phenology of Ecosystem Processes: Applications in Global Change Research (ed A. Noormets), pp. 187-199. Springer Verlag,, Dordrecht ; New York.

Davis S.D., Sperry J.S. \& Hacke U.G. (1999) The relationship between xylem conduit diameter and cavitation caused by freezing. American Journal of Botany, 86, 13671372.

De la Barrera E. \& Nobel P.S. (2004) Nectar: properties, floral aspects, and speculations on origin. Trends in Plant Science, 9, 65-69.

De Schepper V., De Swaef T., Bauweraerts I. \& Steppe K. (2013) Phloem transport: a review of mechanisms and controls. Journal of Experimental Botany, 64, 4839-4850.

Dijkstra F.A., Carrillo Y., Pendall E. \& Morgan J.A. (2013) Rhizosphere priming: a nutrient perspective. Frontiers in Microbiology, 4, 1-8.

Dölger J., Rademaker H., Liesche J., Schulz A. \& Bohr T. (2014) Diffusion and bulk flow in phloem loading: A theoretical analysis of the polymer trap mechanism for sugar transport in plants. Physical Review E, 90, 042704. 
Duursma R.A. \& Medlyn B.E. (2012) MAESPA: a model to study interactions between water limitation, environmental drivers and vegetation function at tree and stand levels, with an example application to $\mathrm{CO} 2 \mathrm{x}$ drought interactions. Geoscientific Model Development, 5, 919-940.

Elser J.J., Fagan W.F., Denno R.F., Dobberfuhl D.R., Folarin A., Huberty A., . . . Sterner R.W. (2000) Nutritional constraints in terrestrial and freshwater food webs. Nature, 408, 578-580.

Elzinga J.A., Atlan A., Biere A., Gigord L., Weis A.E. \& Bernasconi G. (2007) Time after time: flowering phenology and biotic interactions. Trends In Ecology \& Evolution, 22, 432-439.

Ewers F.W. (1985) Xylem structure and water conduction in conifer trees, dicot trees, and lianas. IAWA Bulletin, 6, 309-317.

Falster D.S., Brännström Å., Dieckmann U. \& Westoby M. (2011) Influence of four major plant traits on average height, leaf-area cover, net primary productivity, and biomass density in single-species forests: a theoretical investigation. Journal of Ecology, 99, $148-164$.

Farrar J.F. \& Jones D.L. (2000) The control of carbon acquisition by roots. New Phytologist, 147, 43-53.

Feild T.S., Chatelet D.S. \& Brodribb T.J. (2009) Ancestral xerophobia: a hypothesis on the whole plant ecophysiology of early angiosperms. Geobiology, 7, 237-264.

Feldpausch T.R., Lloyd J., Lewis S.L., Brienen R.J.W., Gloor M., Monteagudo Mendoza A., . .. Phillips O.L. (2012) Tree height integrated into pantropical forest biomass estimates. Biogeosciences, 9, 3381-3403. 
Ferrieri A.P., Appel H., Ferrieri R.A. \& Schultz J.C. (2012) Novel application of 2- F-18 fluoro-2-deoxy-D-glucose to study plant defenses. Nuclear Medicine and Biology, 39, $1152-1160$.

Fine P.V.A., Mesones I. \& Coley P.D. (2004) Herbivores promote habitat specialization by trees in amazonian forests. Science, 305, 663-665.

Fisher D.B. (2000) Long-distance transport. In: Biochemistry and Molecular Biology of Plants (eds B.B. Buchanan, W. Gruissem, \& R.L. Jones), pp. 730-784. American Society of Plant Physiologists, Rockville, MD.

Friend A.D. (1995) PGEN - An integrated model of leaf photosynthesis, transpiration , and conductance. Ecological Modelling, 77, 233-255.

Froelich D.R., Mullendore D.L., Jensen K.H., Ross-Elliott T.J., Anstead J.A., Thompson G.A., . . Knoblauch M. (2011) Phloem ultrastructure and pressure flow: Sieveelement-occlusion-related agglomerations do not affect translocation. Plant Cell, 23, $4428-4445$.

Fu Q., Cheng L., Guo Y. \& Turgeon R. (2011) Phloem loading strategies and water relations in trees and herbaceous plants. Plant Physiology, 157, 1518-1527.

Futuyma D.J. \& Agrawal A.A. (2009) Macroevolution and the biological diversity of plants and herbivores. Proceedings of the National Academy of Sciences, 106, 18054-18061.

Galen C. (2005) It never rains but then it pours: The diverse effects of water on flower integrity and function. In: Reproductive Allocation in Plants (eds E.G. Reekie \& F.A. Bazzaz), pp. 75-93. Academic Press, Burlington, MA, USA.

Gamalei Y. (1989) Structure and function of leaf minor veins in trees and herbs: A taxonomic review. Trees-Structure and Function, 3, 96-110.

Geiger D.R., Malone J. \& Cataldo D.A. (1971) Structural evidence for the theory of vein loading of translocate. American Journal of Botany, 58, 672-675. 
Gershenzon J. (1994) Metabolic costs of terpenoids accumulation in higher-plants. Journal of Chemical Ecology, 20, 1281-1328.

Giardina C.P., Litton C.M., Crow S.E. \& Asner G.P. (2014) Warming-related increases in soil CO2 effux are explained by increased below-ground carbon flux. Nature Climate Change, 4, 822-827.

Giardina C.P. \& Ryan M.G. (2002) Total belowground carbon allocation in a fast-growing Eucalyptus plantation estimated using a carbon balance approach. Ecosystems, 5, 487499.

Givnish T.J. (1995) Plant stems: biomechanical adaptations for energy capture and influence on species distributions. In: Plant stems: physiology and functional morphology (ed B.L. Gartner), pp. 3-49. Chapman and Hall, New York.

Givnish T.J., Wong S.C., Stuart-Williams H., Holloway-Phillips M. \& Farquhar G.D. (2014) Determinants of maximum tree height in Eucalyptus species along a rainfall gradient in Victoria, Australia. Ecology, 95, 2991-3007.

Godschalx A.L., Schädler M., Trisel J.A., Balkan M.A. \& Ballhorn D.J. (2014) Ants are less attracted to the extrafloral nectar of plants with symbiotic, nitrogen-fixing rhizobia. Ecology, 96, 348-354.

Gómez S., Ferrieri R.A., Schueller M. \& Orians C.M. (2010) Methyl jasmonate elicits rapid changes in carbon and nitrogen dynamics in tomato. New Phytologist, 188, 835-844. Gowan E., Lewis B.A. \& Turgeon R. (1995) Phloem transport of antirrhinoside, an iridoid glycoside, in Asarina scandens (Scrophulariaceae). Journal of Chemical Ecology, 21, $1781-1788$.

Greer D.H. \& Rogiers S.Y. (2009) Water flux of Vitis vinifera L. cv. Shiraz bunches throughout development and in relation to late-season weight loss. American Journal of Enology and Viticulture, 60, 155-163. 
Griffiths B.S., Christensen S. \& Bonkowski M. (2007) Microfaunal interactions in the rhizosphere, how nematodes and protozoa link above- and belowground processes. In:

The Rhizosphere: An Ecological Perspective (eds Z.G. Cardon \& J.L. Whitbeck), pp. 57-71. Elsevier Academic Press, Amsterdam ; Boston.

Grime J.P. (2006) Trait convergence and trait divergence in herbaceous plant communities: Mechanisms and consequences. Journal Of Vegetation Science, 17, 255-260.

Hacke U.G. \& Sperry J.S. (2001) Functional and ecological xylem anatomy. Perspectives in Plant Ecology Evolution and Systematics, 4, 97-115.

Hacke U.G., Sperry J.S., Pockman W.T., Davis S.D. \& McCulloch K.A. (2001) Trends in wood density and structure are linked to prevention of xylem implosion by negative pressure. Oecologia, 126, 457-461.

Hall A.J., Minchin P.E.H., Clearwater M.J. \& Génard M. (2013) A biophysical model of kiwifruit (Actinidia deliciosa) berry development. Journal of Experimental Botany, 64, 5473-5483.

Hanson P.J., Edwards N.T., Garten C.T. \& Andrews J.A. (2000) Separating root and soil microbial contributions to soil respiration: A review of methods and observations. Biogeochemistry, 48, 115-146.

Hartmann A., Schmid M., Tuinen D. \& Berg G. (2009) Plant-driven selection of microbes.

Plant and Soil, 321, 235-257.

Haywood V., Yu T.S., Huang N.C. \& Lucas W.J. (2005) Phloem long-distance trafficking of Gibberellic acid-insensitive RNA regulates leaf development. Plant Journal, 42, 4968.

Heard S.B. \& Buchanan C.K. (1998) Larval performance and association within and between two species of hackberry nipple gall insects, Pachypsylla spp. (Homoptera : Psyllidae). American Midland Naturalist, 140, 351-357. 
Heil M. \& Ton J. (2008) Long-distance signalling in plant defence. Trends in Plant Science, 13, 264-272.

Herms D.A. \& Mattson W.J. (1992) The dilemma of plants - To grow or defend. Quarterly Review of Biology, 67, 283-335.

Hickler T., Prentice I.C., Smith B., Sykes M.T. \& Zaehle S. (2006) Implementing plant hydraulic architecture within the LPJ Dynamic Global Vegetation Model. Global Ecology and Biogeography, 15, 567-577.

Higuchi H. \& Sakuratani T. (2005) The sap flow in the peduncle of the mango (Mangifera indica L.) inflorescence as measured by the stem heat balance method. Journal of the Japanese Society for Horticultural Science, 74, 109-114.

Hoch G. (2005) Fruit-bearing branchlets are carbon autonomous in mature broad-leaved temperate forest trees. Plant, Cell and Environment, 28, 651-659.

Högberg P., Nordgren A., Buchmann N., Taylor A.F.S., Ekblad A., Högberg M.N., . . Read D.J. (2001) Large-scale forest girdling shows that current photosynthesis drives soil respiration. Nature, 411, 789-792.

Högberg P. \& Read D.J. (2006) Towards a more plant physiological perspective on soil ecology. Trends in Ecology and Evolution, 21, 548-554.

Holland J.N., Cheng W.X. \& Crossley D.A. (1996) Herbivore-induced changes in plant carbon allocation: Assessment of below-ground C fluxes using carbon-14. Oecologia, 107, 87-94.

Hölttä T., Mencuccini M. \& Nikinmaa E. (2009) Linking phloem function to structure: Analysis with a coupled xylem-phloem transport model. Journal of Theoretical Biology, 259, 325-337. 
Hölttä T., Vesala T., Sevanto S., Peramaki M. \& Nikinmaa E. (2006) Modeling xylem and phloem water flows in trees according to cohesion theory and Munch hypothesis. Trees-Structure and Function, 20, 67-78.

Honkanen T., Haukioja E. \& Kitunen V. (1999) Responses of Pinus sylvestris branches to simulated herbivory are modified by tree sink/source dynamics and by external resources. Functional Ecology, 13, 126-140.

Inbar M., Eshel A. \& Wool D. (1995) Interspecific competition among phloem-feeding insects mediated by induced host-plant sinks. Ecology, 76, 1506-1515.

Jacobsen A.L., Agenbag L., Esler K.J., Pratt R.B., Ewers F.W. \& Davis S.D. (2007) Xylem density, biomechanics and anatomical traits correlate with water stress in 17 evergreen shrub species of the Mediterranean-type climate region of South Africa. Journal of Ecology, 95, 171-183.

Janssens I.A., Lankreijer H., Matteucci G., Kowalski A.S., Buchmann N., Epron D., . . . Valentini R. (2001) Productivity overshadows temperature in determining soil and ecosystem respiration across European forests. Global Change Biology, 7, 269-278.

Janzen D.H. (1970) Herbivores and the number of tree species in tropical forests. American Naturalist, 104, 501-529.

Jensen K.H., Lee J., Bohr T., Bruus H., Holbrook N.M. \& Zwieniecki M.A. (2011)

Optimality of the Munch mechanism for translocation of sugars in plants. Journal of the Royal Society Interface, 8, 1155-1165.

Jensen K.H., Savage J.A. \& Holbrook N.M. (2013) Optimal concentration for sugar transport in plants. Journal of the Royal Society Interface, $\mathbf{1 0 .}$

Jiang F., Chen L., Belimov A.A., Shaposhnikov A.I., Gong F., Meng X., . . Dodd I.C. (2012) Multiple impacts of the plant growth-promoting rhizobacterium Variovorax 
paradoxus 5C-2 on nutrient and ABA relations of Pisum sativum. Journal of Experimental Botany, 63, 6421-6430.

Johnson D., Leake J.R., Ostle N., Ineson P. \& Read D.J. (2002) In situ (CO2)-C-13 pulselabelling of upland grassland demonstrates a rapid pathway of carbon flux from arbuscular mycorrhizal mycelia to the soil. New Phytologist, 153, 327-334.

Jones C.G., Hopper R.F., Coleman J.S. \& Krischik V.A. (1993) Control of systemically induced herbivore resistance by plant vascular architecture. Oecologia, 93, 452-456.

Jones D., Nguyen C. \& Finlay R. (2009) Carbon flow in the rhizosphere: carbon trading at the soil-root interface. Plant and Soil, 321, 5-33.

Joshi P.A., Caetanoanolles G., Graham E.T. \& Gresshoff P.M. (1993) Ultrastructure of transfer cells in spontaneous nodules of alfalfa (Medicago sativa). Protoplasma, $\mathbf{1 7 2}$, 64-76.

Jyske T. \& Hölttä T. (2015) Comparison of phloem and xylem hydraulic architecture in Picea abies stems. New Phytologist, 205, 102-115.

Kaplan I. \& Denno R.F. (2007) Interspecific interactions in phytophagous insects revisited: a quantitative assessment of competition theory. Ecology Letters, 10, 977-994.

Kaplan I., Halitschke R., Kessler A., Sardanelli S. \& Denno R.F. (2008) Constitutive and induced defenses to herbivory in above- and belowground plant tissues. Ecology, 89, 392-406.

Kayler Z., Gessler A. \& Buchmann N. (2010) What is the speed of link between aboveground and belowground processes? New Phytologist, 187, 886-888.

Kerstiens G. \& Possell M. (2001) Is competence for isoprene emission related to the mode of phloem loading? New Phytologist, 152, 368-372.

King D.A. (1991) Tree allometry, leaf size and adult tree size in old-growth forests of western Oregon. Tree Physiol, 9, 369-381. 
Knoblauch M., Froelich D.R., Pickard W.F. \& Peters W.S. (2014) SEORious business: structural proteins in sieve tubes and their involvement in sieve element occlusion. Journal of Experimental Botany, 65, 1879-1893.

Knoblauch M. \& Mullendore D.L. (2012) Sieve element occlusion. In: Phloem: Molecular Cell Biology, Systemic Communication, Biotic Interactions (eds G.A. Thompson \& A.J.E. van Bel), pp. 141-153. John Wiley \& Sons, Ames, IA.

Knoblauch J., Mullendore D.L., Jensen K.H. \& Knoblauch M. (2014) Pico gauges for minimally invasive intracellular hydrostatic pressure measurements. Plant Physiology, 166, 1271-1279.

Knoblauch M. \& Oparka K. (2012) The structure of the phloem - still more questions than answers. Plant Journal, 70, 147-156.

Knoblauch M. \& Peters W.S. (2010) Munch, morphology, microfluidics - our structural problem with the phloem. Plant, Cell and Environment, 33, 1439-1452.

Körner C. (2003) Carbon limitation in trees. Journal of Ecology, 91, 4-17.

Kuzyakov Y. \& Gavrichkova O. (2010) Time lag between photosynthesis and carbon dioxide efflux from soil: a review of mechanisms and controls. Global Change Biology, 16, 3386-3406.

Lalonde S., Tegeder M., Throne-Holst M., Frommer W.B. \& Patrick J.W. (2003) Phloem loading and unloading of sugars and amino acids. Plant, Cell and Environment, 26, $37-56$.

Larson K.C. \& Whitham T.G. (1991) Manipulation of food resources by gall-forming aphid The physiology of sink-source interactions. Oecologia, 88, 15-21.

Larson K.C. \& Whitham T.G. (1997) Competition between gall aphids and natural plant sinks: Plant architecture affects resistance to galling. Oecologia, 109, 575-582. 
Lebon A., Mailleret L., Dumont Y. \& Grognard F. (2014) Direct and apparent compensation in plant-herbivore interactions. Ecological Modelling, 290, 192-203.

Lee B., Lee S. \& Ryu C. (2013) Above ground aphid feeding attracts belowground plant growth-promoting rhizobacteria and primes plant immunity in pepper. Paper presented at the Recent advances in biofertilizers and biofungicides (PGPR) for sustainable agriculture. Proceedings of 3rd Asian Conference on Plant GrowthPromoting Rhizobacteria (PGPR) and other Microbials, Manila, Philippines.

Lemoine R., La Camera S., Atanassova R., Dédaldéechamp F., Allario T., Pourtau N., .. . Durand M. (2013) Source-to-sink transport of sugar and regulation by environmental factors. Frontiers in Plant Science, 4.

Liesche J., Martens H.J. \& Schulz A. (2011) Symplasmic transport and phloem loading in gymnosperm leaves. Protoplasma, 248, 181-190.

Lin J.C. (1997) Water relations of cotton flowers, Harvard University, Cambridge, MA.

Logan B.A., Monson R.K. \& Potosnak M.J. (2000) Biochemistry and physiology of foliar isoprene production. Trends in Plant Science, 5, 477-481.

Lohaus G. \& Schwerdtfeger M. (2014) Comparison of sugars, iridoid glycosides and amino acids in nectar and phloem sap of Maurandya barclayana, Lophospermum erubescens, and Brassica napus. Plos One, 9.

Lucas W.J., Groover A., Lichtenberger R., Furuta K., Yadav S.R., Helariutta Y., . . Kachroo P. (2013) The plant vascular system: Evolution, development and functions. Journal of Integrative Plant Biology, 55, 294-388.

Mackay D.S., Ewers B.E., Loranty M.M., Kruger E.L. \& Samanta S. (2012) Bayesian analysis of canopy transpiration models: A test of posterior parameter means against measurements. Journal of Hydrology, 432, 75-83. 
Malhi Y., Baldocchi D.D. \& Jarvis P.G. (1999) The carbon balance of tropical, temperate and boreal forests. Plant, Cell and Environment, 22, 715-740.

Matthews M.A. \& Shackel K.A. (2005) Growth and water transport in fleshy fruit. In: Vascular transport in plants (eds N.M. Holbrook \& M.A. Zwieniecki), pp. 181-197. Elsevier Academic Press, San Diego.

Mazzeo M., Dichio B., Clearwater M.J., Montanaro G. \& Xiloyannis C. (2013) Hydraulic resistance of developing Actinidia fruit. Annals of Botany, 12, 197-205.

McCulloh K.A. \& Sperry J.S. (2005) Patterns in hydraulic architecture and their implications for transport efficiency. Tree Physiology, 25, 257-267.

McCulloh K.A., Sperry J.S. \& Adler F.R. (2003) Water transport in plants obeys Murray's law. Nature, 421, 939-942.

McDowell N.G., Bond B.J., Dickman L.T., Ryan M.G. \& Whitehead D. (2011) Relationship between tree height and carbon isotope discrimination. In: Size- and Age-Related Changes in Tree Structure and Function (eds F.C. Meinzer, B. Lachenbruch, \& T.E. Dawson), pp. 255-286. Springer, New York.

McDowell N.G., Fisher R.A., Xu C.G., Domec J.C., Hölttä T., Mackay D.S., . . Pockman W.T. (2013) Evaluating theories of drought-induced vegetation mortality using a multimodel-experiment framework. New Phytologist, 200, 304-321.

McDowell N.G. \& Sevanto S. (2010) The mechanisms of carbon starvation: how, when, or does it even occur at all? New Phytologist, 186, 264-266.

McNaughton S.J. (1983) Compensatory plant - Growth as a response to herbivory. Oikos, 40, $329-336$.

Meier I.C., Avis P.G. \& Phillips R.P. (2012) Fungal communities influence root exudation rates in pine seedlings. FEMS Microbiology Ecology, 1-11. 
Mencuccini M. (2002) Hydraulic constraints in the functional scaling of trees. Tree Physiology, 22, 553-565.

Mencuccini M. \& Hölttä T. (2010a) On light bulbs and marbles. Transfer times and teleconnections in plant fluid transport systems. New Phytologist, 187, 889-891.

Mencuccini M. \& Hölttä T. (2010b) The significance of phloem transport for the speed with which canopy photosynthesis and belowground respiration are linked. New Phytologist, 185, 189-203.

Mencuccini M., Hölttä T. \& Martínez-Vilalta J. (2011) Comparative criteria for models of the vascular transport systems of tall trees. In: Size- and Age-Related Changes in Tree Structure and Function (eds F.C. Meinzer, B. Lachenbruch, \& T.E. Dawson), pp. 309-339. Springer, Netherlands.

Meyer S., Lauterbach C., Niedermeier M., Barth I., Sjolund R.D. \& Sauer N. (2004) Wounding enhances expression of AtSUC3, a sucrose transporter from Arabidopsis sieve elements and sink tissues. Plant Physiology, 134, 684-693.

Migliavacca M., Reichstein M., Richardson A.D., Colombo R., Sutton M.A., Lasslop G., . . . van der Molen M.K. (2011) Semiempirical modeling of abiotic and biotic factors controlling ecosystem respiration across eddy covariance sites. Global Change Biology, 17, 390-409.

Minchin P.E.H. \& Lacointe A. (2005) New understanding on phloem physiology and possible consequences for modelling long-distance carbon transport. New Phytologist, 166, 771-779.

Mullendore D.L., Windt C.W., Van As H. \& Knoblauch M. (2010) Sieve tube geometry in relation to phloem flow. Plant Cell, 22, 579-593.

Münch E. (1930) Die stoffbewegungen in der pflanze. Gustav Fischer, Jena, Germany. 
Nemani R.R., Keeling C.D., Hashimoto H., Jolly W.M., Piper S.C., Tucker C.J., . . . Running S.W. (2003) Climate-driven increases in global terrestrial net primary production from 1982 to 1999. Science, 300, 1560-1563.

Nguyen C. (2003) Rhizodeposition of organic C by plants: mechanisms and controls. Agronomie, 23, 375-396.

Nikinmaa E., Hölttä T., Hari P., Kolari P., Mäkelä A., Sevanto S. \& Vesala T. (2013) Assimilate transport in phloem sets conditions for leaf gas exchange. Plant, Cell and Environment, 36, 655-669.

Nobel P.S., Andrade J.L., Wang N. \& North G.B. (1994) Water potentials for developing cladodes and fruits of a succulent plant, including xylem-versus-phloem implications for water-movement. Journal of Experimental Botany, 45, 1801-1807.

Nobel P.S. \& De la Barrera E. (2000) Carbon and water balances for young fruits of platyopuntias. Physiologia Plantarum, 109, 160-166.

Nowak R.S. \& Caldwell M.M. (1984) A test of compensatory photosynthesis in the field Implications for herbivory tolerance. Oecologia, 61, 311-318.

O'Brien M.J., Leuzinger S., Philipson C.D., Tay J. \& Hector A. (2014) Drought survival of tropical tree seedlings enhanced by non-structural carbohydrate levels. Nature Climate Change, 4, 710-714.

Ogée J., Brunet Y., Loustau D., Berbigier P. \& Delzon S. (2003) MuSICA, a CO2, water and energy multilayer, multileaf pine forest model: evaluation from hourly to yearly time scales and sensitivity analysis. Global Change Biology, 9, 697-717.

Ohya T., Tanoi K., Hamada Y., Okabe H., Rai H., Hojo J., . . Nakanishi T.M. (2008) An analysis of long-distance water transport in the soybean stem using $\mathrm{H}(2)(15) \mathrm{O}$. Plant and Cell Physiology, 49, 718-729. 
Orians C. (2005) Herbivores, vascular pathways, and systemic induction: Facts and artifacts. Journal of Chemical Ecology, 31, 2231-2242.

Orians C.M., Thorn A. \& Gómez S. (2011) Herbivore-induced resource sequestration in plants: why bother? Oecologia, 167, 1-9.

Parsons R., Stanforth A., Raven J.A. \& Sprent J.I. (1993) Nodule growth and activity may be regulated by a feedback mechanism involving phloem nitrogen. Plant, Cell and Environment, 16.

Patrick J.W. (1997) Phloem unloading: Sieve element unloading and post-sieve element transport. Annual Review of Plant Physiology and Plant Molecular Biology, 48, 191222.

Patrick J.W. (2013) Does Don Fisher's high-pressure manifold model account for phloem transport and resource partitioning? Frontiers in Plant Science, 4.

Peel A.J. \& Ho L.C. (1970) Colony size of Tuberolachnus salignus (Gmelin) in relation to mass transport of 14C-labelled assimilates from the leaves in Willow. Physiologia Plantarum, 23, 1033-1038.

Peiter E. \& Schubert S. (2003) Sugar uptake and proton release by protoplasts from the infected zone of Vicia faba L. nodules: evidence against apoplastic sugar supply of infected cells. Journal of Experimental Botany, 54, 1691-1700.

Peterson R.L. \& Massicotte H.B. (2004) Exploring structural definitions of mycorrhizas, with emphasis on nutrient-exchange interfaces. Canadian Journal of Botany-Revue Canadienne de Botanique, 82, 1074-1088.

Petit G. \& Crivellaro A. (2014) Comparative axial widening of phloem and xylem conduits in small woody plants. Trees-Structure and Function, 28, 915-921.

Pichersky E. \& Gershenzon J. (2002) The formation and function of plant volatiles: perfumes for pollinator attraction and defense. Current Opinion in Plant Biology, 5, 237-243. 
Preston K.A., Cornwell W.K. \& DeNoyer J.L. (2006) Wood density and vessel traits as distinct correlates of ecological strategy in 51 California coast range angiosperms. New Phytologist, 170, 807-818.

Reich P.B. (2014) The world-wide 'fast-slow' plant economics spectrum: a traits manifesto. Journal of Ecology, 102, 275-301.

Reidel E.J., Rennie E.A., Amiard V., Cheng L.L. \& Turgeon R. (2009) Phloem loading strategies in three plant species that transport sugar alcohols. Plant Physiology, 149, 1601-1608.

Rennie E.A. \& Turgeon R. (2009) A comprehensive picture of phloem loading strategies. Proceedings of the National Academy of Sciences of the United States of America, 106, $14162-14167$.

Roddy A.B., Guilliams C.M., Lilittham T., Farmer J., Wormser V., Pham T., . . D Dawson T.E. (2013) Uncorrelated evolution of leaf and petal venation patterns across the angiosperm phylogeny. Journal of Experimental Botany, 64, 4081-4088.

Rosenkranz H., Vogel R., Greiner S. \& Rausch T. (2001) In wounded sugar beet (Beta vulgaris L.) tap-root, hexose accumulation correlates with the induction of a vacuolar invertase isoform. Journal of Experimental Botany, 52, 2381-2385.

Ryan M.G., Phillips N. \& Bond B.J. (2006) The hydraulic limitation hypothesis revisited. Plant, Cell and Environment, 29, 367-381.

Ryan M.G. \& Yoder B.J. (1997) Hydrauilc limits to tree height and tree growth. Bioscience, 47, 235-242.

Sala A., Piper F. \& Hoch G. (2010) Physiological mechanisms of drought-induced tree mortality are far from being resolved. New Phytologist, 186, 274-281.

Sala A., Woodruff D.R. \& Meinzer F.C. (2012) Carbon dynamics in trees: feast or famine? Tree Physiology, 32, 764-775. 
Salleo S., Lo Gullo M.A., Trifilò P. \& Nardini A. (2004) New evidence for a role of vesselassociated cells and phloem in the rapid xylem refilling of cavitated stems of Laurus nobilis L. Plant, Cell and Environment, 27, 1065-1076.

Sauter J.J. (1982) Efflux and reabsorption of sugars in the xylem. 1. Seasonal-changes in sucrose efflux in Salix Zeitschrift Fur Pflanzenphysiologie, 106, 325-336.

Savage J.A., Haines D.F. \& Holbrook N.M. (2015) The making of giant pumpkins: How selective breeding changed the phloem of Cucurbita maxima from source to sink. Plant, Cell and Environment, 38.

Savage J.A., Zwieniecki M.A. \& Holbrook N.M. (2013) Phloem transport velocity varies over time and among vacular bundles during early cucumber seedling development. Plant Physiology, 163, 1409-1418.

Schiestl-Aalto P., Kulmala L., Mäkinen H., Nikinmaa E. \& Mäkelä A. (2015) CASSIA - a dynamic model for predicting intra-annual sink demand and inter-annual growth variation in Scots pine. New Phytologist, 206, 647-659.

Schill V., Hartung W., Orthen B. \& Weisenseel M.H. (1996) The xylem sap of maple (Acer platanoides) trees - Sap obtained by a novel method shows changes with season and height. Journal of Experimental Botany, 47, 123-133.

Schultz J.C., Appel H.M., Ferrieri A.P. \& Arnold T.M. (2013) Flexible resource allocation during plant defense responses. Frontiers in Plant Science, 4.

Schwachtje J., Minchin P.E.H., Jahnke S., van Dongen J.T., Schittko U. \& Baldwin I.T. (2006) SNF1-related kinases allow plants to tolerate herbivory by allocating carbon to roots. Proceedings of the National Academy of Sciences of the United States of America, 103, 12935-12940. 
Scott-Denton L.E., Rosenstiel T.N. \& Monson R.K. (2006) Differential controls by climate and substrate over the heterotrophic and rhizospheric components of soil respiration. Global Change Biology, 12, 205-216.

Serraj R., Sinclair T.R. \& Purcell L.C. (1999) Symbiotic N-2 fixation response to drought. Journal of Experimental Botany, 50, 143-155.

Sevanto S. (2014) Phloem transport and drought. Journal of Experimental Botany, 65, 17511759.

Sevanto S., Hölttä T. \& Holbrook N.M. (2011) Effects of the hydraulic coupling between xylem and phloem on diurnal phloem diameter variation. Plant, Cell and Environment, 34, 690-703.

Sevanto S., Hölttä T., Markkanen T., Peramaki M., Nikinmaa E. \& Vesala T. (2005) Relationships between diurnal xylem diameter variation and environmental factors in Scots pine. Boreal Environment Research, 10, 447-458.

Sevanto S., Nikinmaa E., Riikonen A., Daley M., Pettijohn J.C., Mikkelsen T.N., . . . Holbrook N.M. (2008) Linking xylem diameter variations with sap flow measurements. Plant and Soil, 305, 77-90.

Sevanto S., Vesala T., Perämäki M. \& Nikinmaa E. (2003) Sugar transport together with environmental conditions controls time lags between xylem and stem diameter changes. Plant, Cell and Environment, 26, 1257-1265.

Shavit R., Ofek-Lalzar M., Burdman S. \& Morin S. (2013) Inoculation of tomato plants with rhizobacteria enhances the performance of the phloem-feeding insect Bemisia tabaci. Frontiers in Plant Science, 4.

Sperry J.S. (2003) Evolution of water transport and xylem structure. International Journal of Plant Sciences, 164, S115-S127. 
Stamp N. (2003) Out of the quagmire of plant defense hypotheses. Quarterly Review of Biology, 78, 23-55.

Subke J.A., Hahn V., Battipaglia G., Linder S., Buchmann N. \& Cotrufo M.F. (2004)

Feedback interactions between needle litter decomposition and rhizosphere activity.

Oecologia, 139, 551-559.

Sulieman S. \& Schulze J. (2010) Phloem-derived gamma-aminobutyric acid (GABA) is involved in upregulating nodule N-2 fixation efficiency in the model legume Medicago truncatula. Plant, Cell and Environment, 33, 2162-2172.

Sulieman S. \& Tran L.S.P. (2013) Asparagine: an amide of particular distinction in the regulation of symbiotic nitrogen fixation of legumes. Critical Reviews in Biotechnology, 33, 309-327.

Tarpley L. \& Sassenrath G.F. (2006) Carbohydrate profiles during cotton floral bud (Square) development. Journal of Agronomy and Crop Science, 192, 363-372.

Tegeder M. (2014) Transporters involved in source to sink partitioning of amino acids and ureides: opportunities for crop improvement. Journal of Experimental Botany, 65, $1865-1878$.

Thompson M.V. \& Holbrook N.M. (2003) Scaling phloem transport: water potential equilibrium and osmoregulatory flow. Plant, Cell and Environment, 26, 1561-1577. Tiffin P. (2000) Mechanisms of tolerance to herbivore damage: what do we know? Evolutionary Ecology, 14, 523-536.

Trolinder N.L., McMichael B.L. \& Upchurch D.R. (1993) Water relations of cotton flower petals and fruit Plant, Cell and Environment, 16, 755-760.

Turck F., Fornara F. \& Coupland G. (2008) Regulation and identity of florigen:

FLOWERING LOCUS T moves center stage. In: Annual Review of Plant Biology, pp. 573-594. Annual Reviews, Palo Alto. 
Turgeon R. (2010a) The puzzle of phloem pressure. Plant Physiology, 154, 578-581.

Turgeon R. (2010b) The role of phloem loading reconsidered. Plant Physiology, 152, 18171823.

Turgeon R. \& Medville R. (1998) The absence of phloem loading in willow leaves.

Proceedings of the National Academy of Sciences of the United States of America, 95, 12055-12060.

Turgeon R. \& Medville R. (2004) Phloem loading. A reevaluation of the relationship between plasmodesmatal frequencies and loading strategies. Plant Physiology, 136, 37953803.

Turgeon R., Medville R. \& Nixon K.C. (2001) The evolution of minor vein phloem and phloem loading. American Journal of Botany, 88, 1331-1339.

Turgeon R. \& Wolf S. (2009) Phloem transport: Cellular pathways and molecular trafficking. Annual Review of Plant Biology, 60, 207-221.

Turnbull C. (2011) Long-distance regulation of flowering time. Journal of Experimental Botany, 62, 4399-4413.

Tyree M.T., Christy A.L. \& Ferrier J.M. (1974) A simpler iterative steady state solution of Münch pressure-flow systems applied to long and short translocation paths. Plant Physiology, 54, 589-600.

Tyree M.T. \& Ewers F.W. (1991) Tansley Review No. 34. The hydraulic architecture of trees and other woody plants. New Phytologist, 119, 345-360.

van Bel A.J.E. (1978) Free space of xylem translocation pathway of tomato stem. Journal of Experimental Botany, 29, 295-303.

van Bel A.J.E. (1990) Xylem-phloem exchange via the rays - The undervalued route of transport Journal of Experimental Botany, 41, 631-644. 
van Bel A.J.E. (2003) The phloem, a miracle of ingenuity. Plant, Cell and Environment, 26, 125-149.

van Bel A.J.E. \& Knoblauch M. (2000) Sieve element and companion cell: the story of the comatose patient and the hyperactive nurse. Functional Plant Biology, 27, 477-487. van Iersel M.W., Oosterhuis D.M. \& Harris W.M. (1994) Apoplastic water-flow to cotton leaves and fruits during development Journal of Experimental Botany, 45, 163-169. Vargas R., Baldocchi D.D., Bahn M., Hanson P.J., Hosman K.P., Kulmala L., . . Yang B. (2011a) On the multi-temporal correlation between photosynthesis and soil CO2 efflux: reconciling lags and observations. New Phytologist, 191, 1006-1017.

Vargas R., Carbone M.S., Reichstein M. \& Baldocchi D.D. (2011b) Frontiers and challenges in soil respiration research: from measurements to model-data integration. Biogeochemistry, 102, 1-13.

Vargas R., Detto M., Baldocchi D.D. \& Allen M.F. (2010) Multiscale analysis of temporal variability of soil $\mathrm{CO} 2$ production as influenced by weather and vegetation. Global Change Biology, 16, 1589-1605.

Voitsekhovskaja O.V., Rudashevskaya E.L., Demchenko K.N., Pakhomova M.V., Batashev D.R., Gamalei Y.V., . . . Pawlowski K. (2009) Evidence for functional heterogeneity of sieve element-companion cell complexes in minor vein phloem of Alonsoa meridionalis. Journal of Experimental Botany, 60, 1873-1883.

Walsh K.B. (1990) Vascular transport and soybean nodule function III. Implications of a continual phloem supply of carbon and water. Plant, Cell and Environment, 13, 893901.

Walsh K.B. (1995) Physiology of the legume nodule and its response to stress. Soil Biology and Biochemistry, 27, 637-655. 
Walters D.R. \& McRoberts N. (2006) Plants and biotrophs: a pivotal role for cytokinins? Trends In Plant Science, 11, 581-586.

Wan X.C., Steudle E. \& Hartung W. (2004) Gating of water channels (aquaporins) in cortical cells of young corn roots by mechanical stimuli (pressure pulses): effects of ABA and of $\mathrm{HgCl}$. Journal of Experimental Botany, 55, 411-422.

Way M.J. (1963) Mutualism between ants and honeydew-producing Homoptera. Annual Review of Entomology, 8, 307-344.

Webb C.O., Gilbert G.S. \& Donoghue M.J. (2006) Phylodiversity-dependent seedling mortality, size structure, and disease in a Bornean rain forest. Ecology, 87, S123S131.

Werner D., Gerlitz N. \& Stadler R. (2011) A dual switch in phloem unloading during ovule development in Arabidopsis. Protoplasma, 248, 225-235.

West G.B., Brown J.H. \& Enquist B.J. (1999) A general model for the structure and allometry of plant vascular systems. Nature, 400, 664-667.

Whipps J.M. (1990) Carbon economy. In: The Rhizosphere (ed J.M. Lynch), pp. 59-97. John Wiley \& Sons, New York.

Will T., Kornemann S.R., Furch A.C.U., Tjallingii W.F. \& van Bel A.J.E. (2009) Aphid watery saliva counteracts sieve-tube occlusion: a universal phenomenon? Journal of Experimental Biology, 212, 3305-3312.

Will T. \& van Bel A.J.E. (2006) Physical and chemical interactions between aphids and plants. Journal of Experimental Botany, 57, 729-737.

Windt C.W. (2007) Nuclear magnetic resonance imaging of sap flow in plants. In: Nuclear magnetic resonance imaging of sap flow in plants. Wageningen Universiteit (Wageningen University), Wageningen Netherlands. 
Windt C.W., Gerkema E. \& van As H. (2009) Most water in the tomato truss is imported through the xylem, not the phloem: a nuclear magnetic resonance flow imaging study. Plant Physiology, 151, 830-842.

Windt C.W., Vergeldt F.J., De Jager P.A. \& Van As H. (2006) MRI of long-distance water transport: a comparison of the phloem and xylem flow characteristics and dynamics in poplar, castor bean, tomato and tobacco. Plant, Cell and Environment, 29, 1715-1729.

Winter H., Lohaus G. \& Heldt H.W. (1992) Phloem transport of amino-acids in relation to their cytosolic levels in barley leaves. Plant Physiology, 99, 996-1004.

Woodruff D.R. (2014) The impacts of water stress on phloem transport in Douglas-fir trees. Tree Physiology, 34, 5-14.

Woodruff D.R. \& Meinzer F.C. (2011) Water stress, shoot growth and storage of nonstructural carbohydrates along a tree height gradient in a tall conifer. Plant, Cell and Environment, 34, 1920-1930.

Wright I.J., Reich P.B., Westoby M., Ackerly D.D., Baruch Z., Bongers F., . . . Villar R. (2004) The worldwide leaf economics spectrum. Nature, 428, 821-827.

Wullschleger S.D. \& Oosterhuis D.M. (1990) Photosynthetic and respiratory activity of fruiting forms within the cotton canopy. Plant Physiology, 94, 463-469.

Xu C.G., Fisher R., Wullschleger S.D., Wilson C.J., Cai M. \& McDowell N.G. (2012) Toward a mechanistic modeling of nitrogen limitation on vegetation dynamics. Plos One, 7.

Yamamoto T. (1983) Models of water competition between fruits and leaves on spurs of 'Bartlett' pear trees and its measurement by a heat-pulse method. Scientia Horticulturae, 20, 241-250. 
Zanne A.E., Tank D.C., Cornwell W.K., Eastman J.M., Smith S.A., FitzJohn R.G., . . . Beaulieu J.M. (2014) Three keys to the radiation of angiosperms into freezing environments. Nature, 506, 89-92.

Zerva A., Ball T., Smith K.A. \& Mencuccini M. (2005) Soil carbon dynamics in a Sitka spruce (Picea sitchensis (Bong.) Carr.) chronosequence on a peaty gley. Forest Ecology and Management, 205, 227-240.

Zhang C., Han L., Slewinski T.L., Sun J., Zhang J., Wang Z.-Y. \& Turgeon R. (2014) Symplastic phloem loading in poplar. Plant Physiology, 166, 306-313.

Zhang L., Cohn N.S. \& Mitchell J.P. (1996) Induction of a pea cell-wall invertase gene by wounding and its localized expression in phloem. Plant Physiology, 112, 1111-1117.

Zhang X.Y., Wang X.L., Wang X.F., Xia G.H., Pan Q.H., Fan R.C., . . Zhang D.P. (2006) A shift of phloem unloading from symplasmic to apoplasmic pathway is involved in developmental onset of ripening in grape berry. Plant Physiology, 142, 220-232.

Zweifel R., Item H. \& Häsler R. (2000) Stem radius changes and their relation to stored water in stems of young Norway spruce trees. Trees-Structure and Function, 15, 50-57.

Zwieniecki M.A., Melcher P.J., Feild T.S. \& Holbrook N.M. (2004) A potential role for xylem-phloem interactions in the hydraulic architecture of trees: effects of phloem girdling on xylem hydraulic conductance. Tree Physiology, 24, 911-917. 


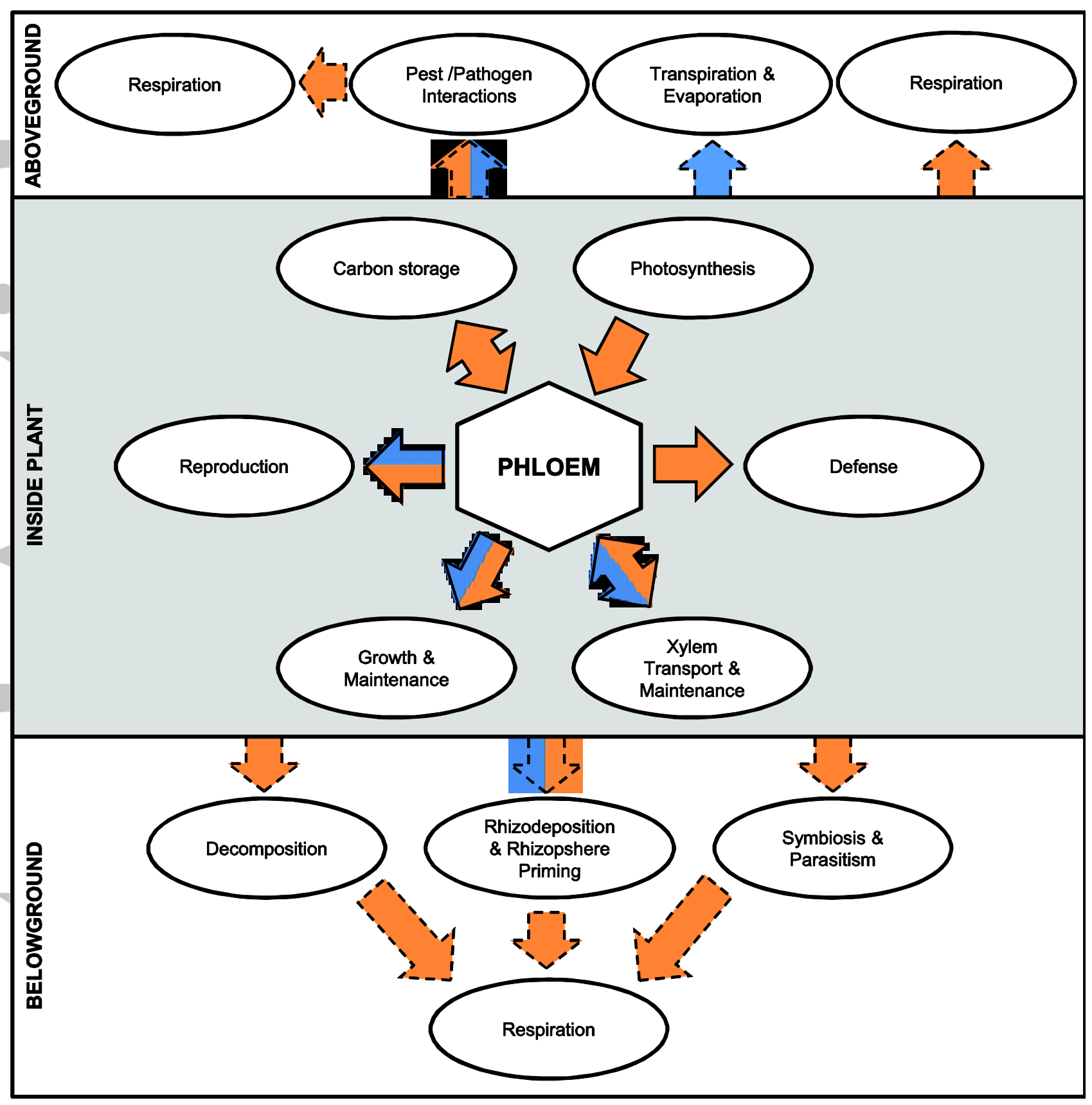

Figure 1. Transport of water and carbon into and out of the phloem. Water and carbon fluxes are noted in blue and orange, respectively and separated based on where they occur (e.g. within the plant, and above- and belowground). Dashed arrows are fluxes that occur outside the plant but originate from resources transported in the phloem. 


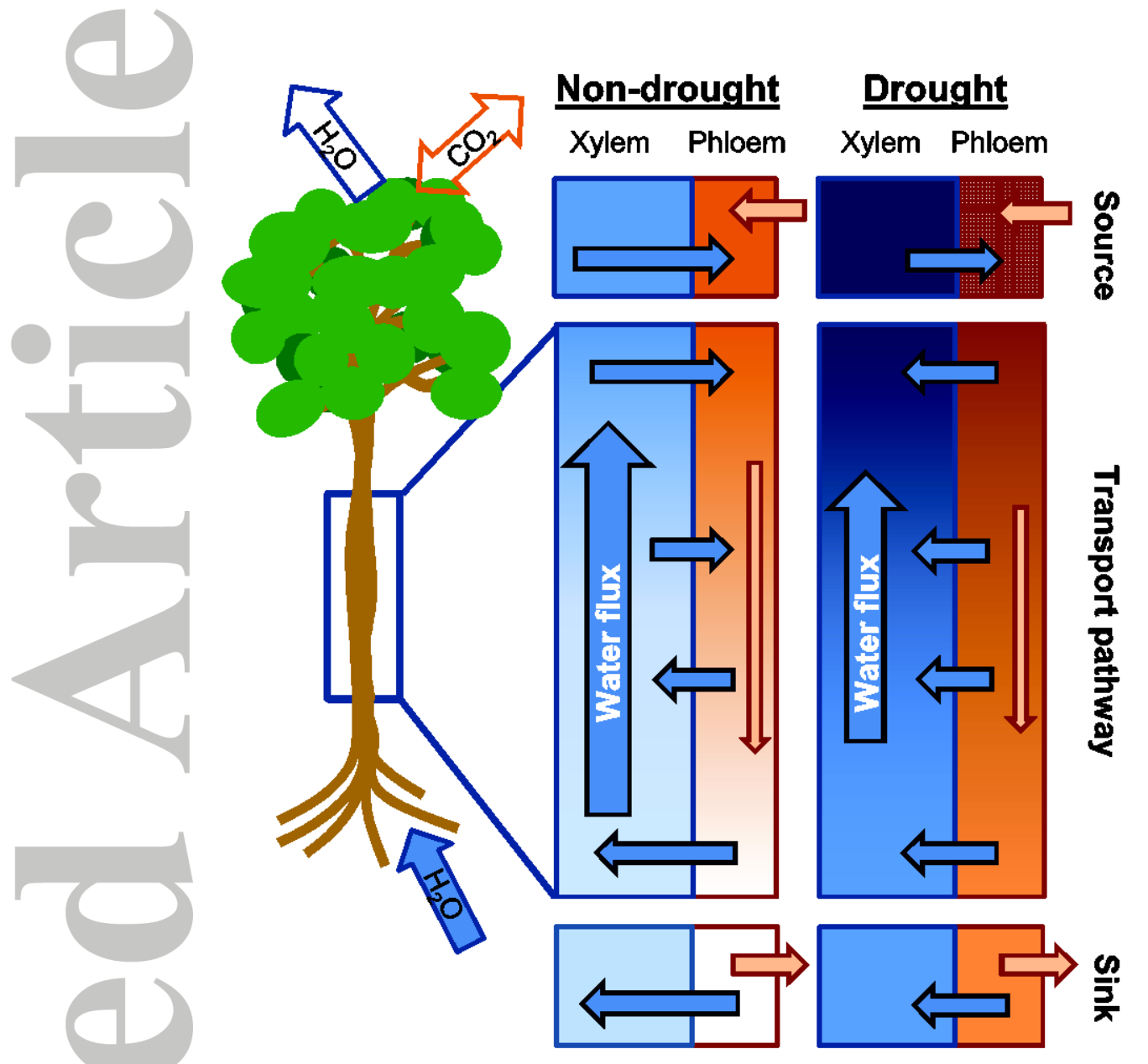

Figure 2. A schematic presentation of water and carbohydrate fluxes between a source leaf and a sink in the stem or roots. Fluxes of water and carbohydrate are represented by blue and orange arrows, respectively, and the length of the arrow indicates the size of the flux. Open arrows are gaseous fluxes. Inside the vascular tissue, darker shades of blue indicate more negative xylem water potentials, and dark shades of orange indicate higher phloem solute concentrations. During non-drought conditions the phloem pulls water from the xylem to support carbohydrate transport. At sinks, carbohydrates are extracted from the transport stream and water returns to the xylem. During drought, increasing solute concentrations are needed in the phloem to prevent excessive water loss to the xylem and allow for phloem turgor maintenance. 


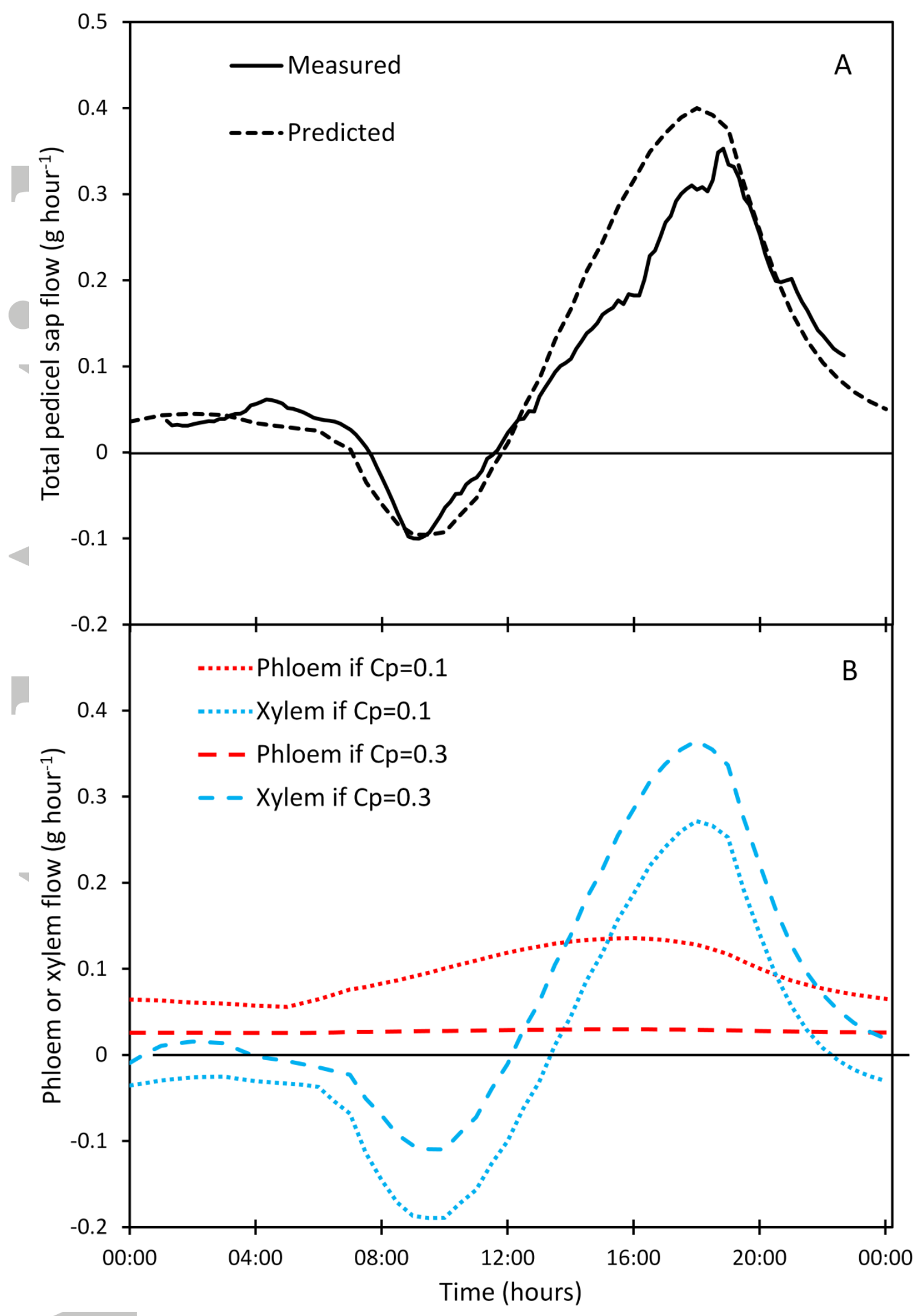

This article is protected by copyright. All rights reserved. 
Figure 3. Measured and modelled time course of sap flow in pedicels of kiwifruit over 24 hours, 65 days after anthesis. A positive flow indicates flow from plant to fruit. A. Total flow (the sum of xylem and phloem flows) measured using sap flow gauges (Clearwater et al. , 2013) and predicted using a biophysical model of fruit development (Hall et al., 2013; Hall, unpublished). B. Model predicted total flow partitioned into component phloem and xylem flows, with mean phloem sap concentration assumed to be at the low $\left(C_{\mathrm{p}}=0.1\right.$; sugar mass fraction) or high $\left(C_{\mathrm{p}}=0.3\right)$ end of likely in-vivo concentrations (Jensen et al., 2013). Xylem flows oscillate between inward and outward flow, and with decreased $C_{\mathrm{p}}$ the magnitude and duration of xylem outflow increases. Model parameters for (B) were adjusted so that total flow matched predicted flow shown in (A).

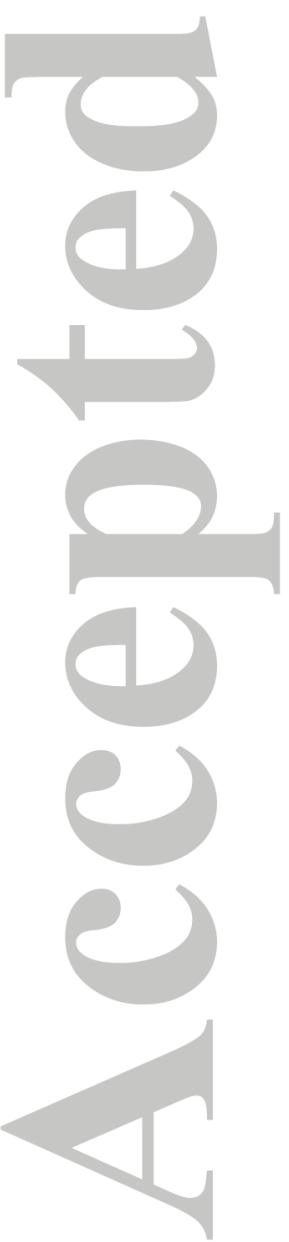


'Black box' model

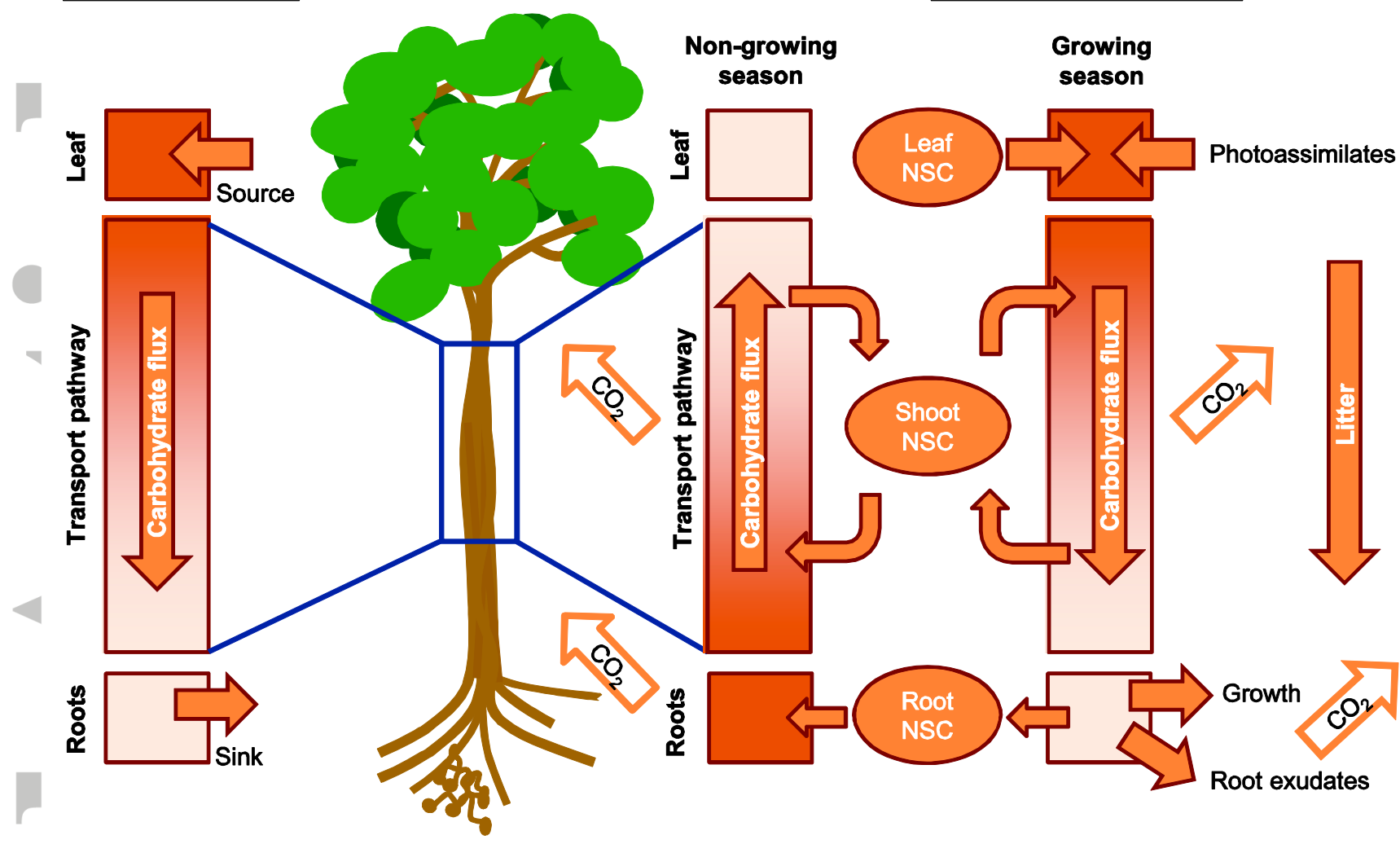

Figure 4. Carbon fluxes in a tree depicted by a simple 'black box model' and one with partitioning among internal carbon pools and their individual fluxes. Partitioned model shows changes that occur between the growing season and non-growing season in terms of the direction of phloem transport and predominant sources and sinks in the system. This model is based on data presented in Klein and Hoch (2015). Gaseous fluxes are noted by open arrows. Non-structural carbohydrates in the form of sugars and starch found in the leaves, trunk and roots are noted as NSC. 

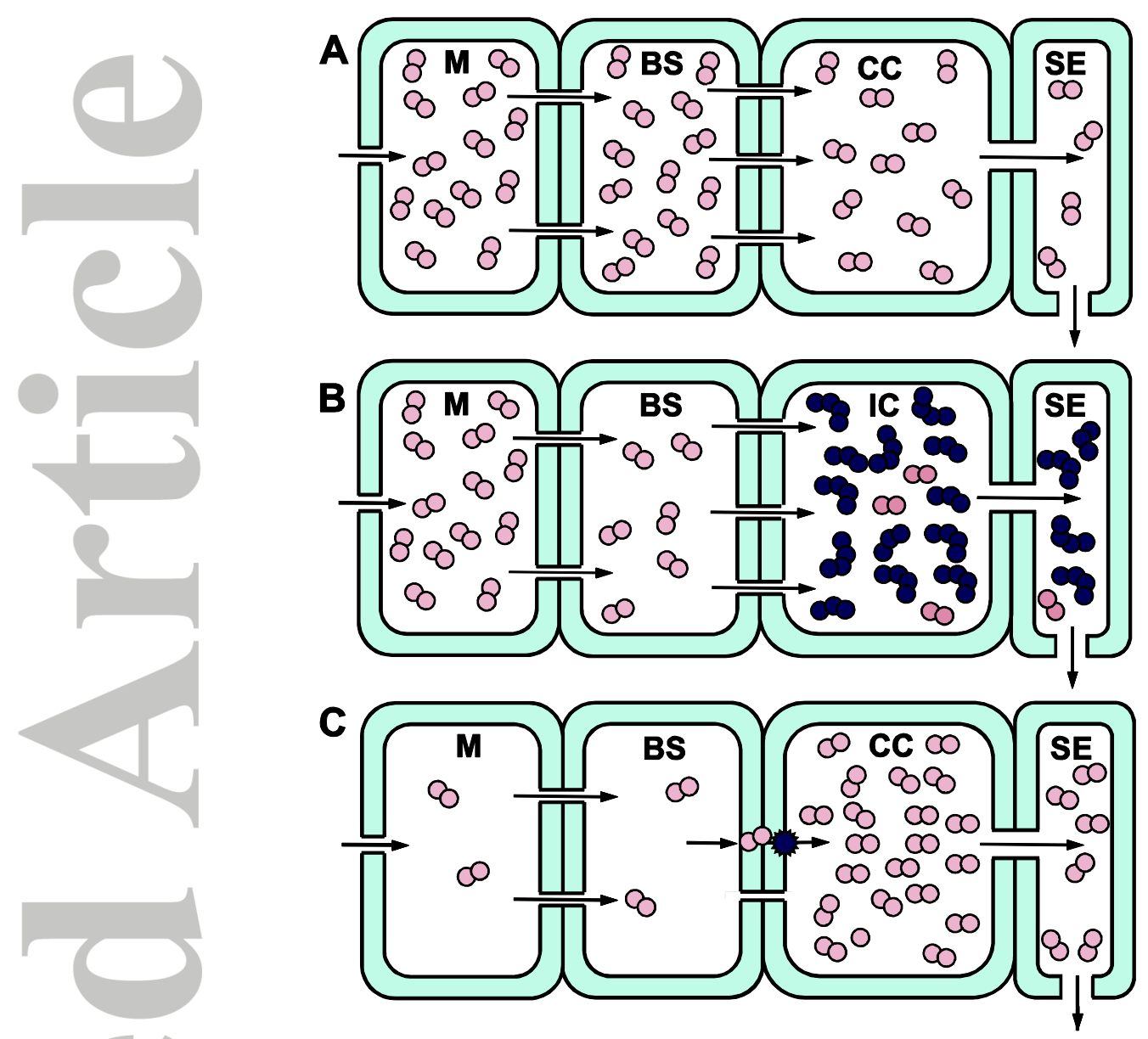

Figure 5. Passive (A), polymer trap (B) and apoplastic (C) phloem loading mechanisms. In A, sucrose (pink) passes through plasmodesmata (arrows) from mesophyll cells (M) to bundle sheath cells (BS) and into companion cells (CC) and sieve elements (SE) down its concentration gradient. In B, sucrose is converted to raffinose and stachyose (blue) in intermediary cells (IC). In C, sucrose is loaded into CC and/or SE by sucrose- $\mathrm{H}^{+}$cotransporters (blue star). Plasmodesmata at the BS-CC interface in apoplastic loaders are present but may be too narrow for sucrose passage. 